\title{
Hydrogen Fuel Cell Analysis: Lessons Learned from Stationary Power Generation
}

\author{
Final Report \\ DE-FG36-07G017107 \\ Prepared for:
}

Fred Joseck

DOE HQ Technology Manager

Hydrogen Program

fred.joseck@ee.doe.gov
Reginald Tyler

DOE Field Project Officer

Golden Field Office

reginald.tyler@go.doe.gov

\section{Prepared by:}

\author{
Dr. Scott E. Grasman, PI
}

Engineering Management and Systems Engineering

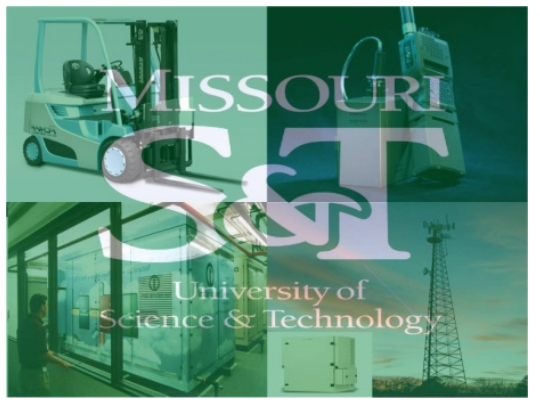

Dr. John W. Sheffield

Dr. Fatih Dogan

Dr. Sunggyu “KB” Lee

Dr. Umit O. Koylu

Ms. Angie Rolufs

Missouri University of Science and Technology 


\section{Executive Summary}

In its review of the Department of Energy's Research, Development and Demonstration (RD\&D) plan for hydrogen, the National Academies recommended that the Department of Energy (DOE) conduct a study of lessons learned from technologies developed for stationary power systems, as well as opportunities for hydrogen in stationary applications, and to make recommendations related to an RD\&D strategy. This strategy should define the various trade-offs and opportunities by systematically incorporating considerations of both transportation and stationary sectors. Thus, the motivation for this project was to identify the lessons learned from prior stationary power programs, including the most significant obstacles, how these obstacles have been approached, outcomes of the programs, and how this information can be used by the Hydrogen, Fuel Cells \& Infrastructure Technologies Program to meet program objectives primarily related to hydrogen pathway technologies (production, storage, and delivery) and implementation of fuel cell technologies for distributed stationary power. In addition, the lessons learned address environmental and safety concerns, including codes and standards, and education of key stakeholders.

In the future, hydrogen-based stationary systems can help supply some or all of the power demanded with additional advantages of higher reliability, lower emissions, independence from the general grid, and cogeneration capability. In order to understand how to prepare the future for this technology, this study conducted a thorough global investigation of past alternative stationary power projects in order for an assessment of the opportunities for and interactions of joint stationary and transportation hydrogen sectors to be completed. Additional qualitative factors were incorporated into a transitional hydrogen supply chain infrastructure model, as required, to provide a comprehensive strategy for stationary power generation.

This study considered opportunities for hydrogen in stationary applications in order to make recommendations related to $\mathrm{RD} \& \mathrm{D}$ strategies that incorporate lessons learned and best practices from relevant national and international stationary power efforts, as well as cost and environmental modeling of pathways. The study analyzed the different strategies utilized in power generation systems and identified the different challenges and opportunities for producing and using hydrogen as an energy carrier. Specific objectives included both a synopsis/critical 
analysis of lessons learned from previous stationary power programs and recommendations for a strategy for hydrogen infrastructure deployment. This strategy incorporates all hydrogen pathways and a combination of distributed power generating stations, and provides an overview of stationary power markets, benefits of hydrogen-based stationary power systems, and competitive and technological challenges.

The role and use of fuel cells in near-term stationary and portable applications (such as residential/base combined heat and power, backup and auxiliary power, grid independent power, specialty vehicles, and portable devices) could be significant, especially if opportunities for integrated systems are considered. During the past 20 years, a number of approaches have been used to encourage the application of alternative fuels and fuel technologies; however, many of these have failed due to lack of a real program management support, shifts in government policies, and/or failure to considered technical experience from previous efforts. Lessons learned with respect to the lack of success and widespread acceptance of fuel cell technologies, as well as other technologies developed for stationary and portable fuel cell systems, may be used to provide recommendations for market research and transformation strategies.

Successful demonstration of fuel cell technologies is crucial to the long-term sustainability of fuel cell technologies; thus, market studies are intertwined within technical research. Therefore, efforts should explicitly address interactions by rigorously considering the science behind, among others, technology status and growth, applications for early market development, consumer behavior and attitudes, impact of infrastructure availability, e.g., cost and environmental parameters, and transitional dynamics of fuel cell technologies, infrastructure, and applications. Lessons learned from prior fuel cell programs, including the most significant obstacles, how these obstacles have been approached, outcomes of the programs, and they can be used to encourage the use of fuel cells are still required.

By acquiring the fuel cell customers/end-users opinion on the current status of the stationary and portable fuel cell markets (through interviews, conferences, meetings, and workshops), knowledge has been gained that addresses what steps should be taken in regard to making recommendations for bringing more customers into the fuel cell market. The understanding of competitive and technological issues related to feasible alternatives allows for effective short and 
long term strategies for addressing the nation’s energy challenges. Highlighted conclusions include:

- The role and use of hydrogen fuel cells in stationary applications can be significant in portable applications, niche markets, distributed generation or co-generation.

- Market penetration is the ultimate goal of the energy related industries, but early markets must be strategically aligned with balancing near term and long term objectives.

- Focus on demonstrating that cost, durability, and reliability can be met for early markets (with incentives, if necessary).

- Consider opportunities and trade-offs for stationary applications in conjunction with the other application sectors, e.g., providing fuel for transportation applications.

- Take a systems perspective - components should address multiple systems.

The ideal candidates for stationary fuel cell deployment include applications that require constant, consistent, reliable, quiet power, can effectively use waste heat for heating and cooling, and have potential uses for by-product hydrogen. While proven and accepted mass market fuel cell technology development and cost reduction is taking longer than expected, some applications have broken the mold and are cost competitive with incumbent technology.

Market barriers include technical considerations, cost competitiveness, fuel flexibility, and public acceptance. These can be addressed through a strategy that:

\section{Continues Demonstration Projects}

2. Focuses on Application Specific Competition

3. Facilitates Investment through Tax Credits, Subsidies, and Financial Partnerships

4. Prioritizes R\&D Efforts

5. Shows Value Proposition through Niche Markets

6. Encourages Integrated Systems

7. Addressed Codes/Standards, Safety and Environment

Future work should continue to address these technical, economic, and social barriers to widespread market growth. 


\section{Table of Contents}

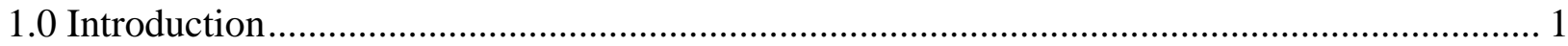

2.0 Summary of Project Methodology ……………….............................................................. 2

2.1 Literature Review ...................................................................................................... 3

2.2 Fuel Cell Project and Program Identification................................................................. 3

2.3 Early Market Development Strategies for Stationary Power Generation ............................... 5

2.4 Site Visits/Meetings ........................................................................................................... 7

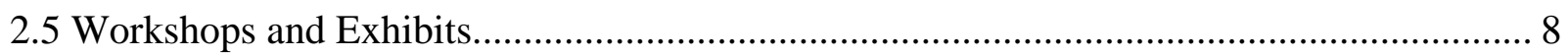

3.0 A Select Listing of Demonstration Projects............................................................................... 8

3.1 Department of Defense Demonstration Projects ................................................................... 8

3.2 Recent Department of Energy Initiatives ............................................................................. 11

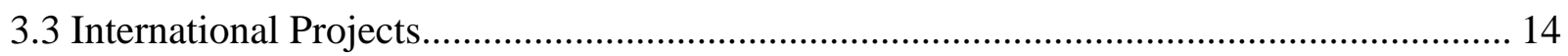

3.4 Other Fuel Cell Initiatives .............................................................................................. 15

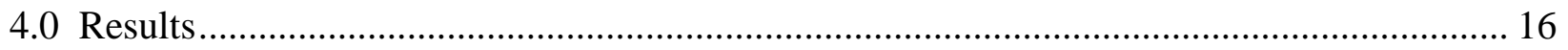

4.1 Program Data (Parts Two and Three) ………………...................................................... 17

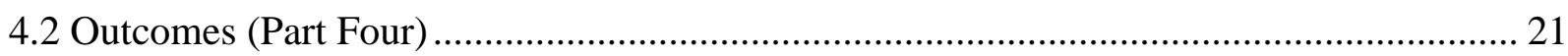

4.3 Lessons Learned (Part Five)........................................................................................... 23

4.4 Early Market Applications (Part Six) ................................................................................ 24

4.5 Policy Instruments (Part Seven) ...................................................................................... 24

5.0 Workshop Results - Stationary \& Portable Fuel Cell Market Transformation and

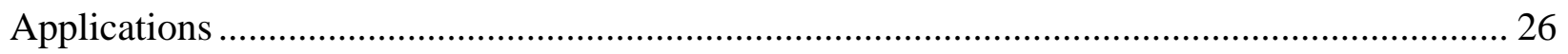

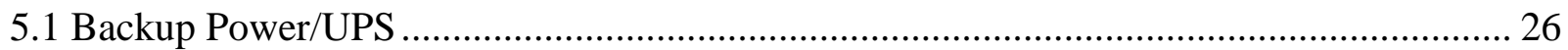

5.2 Combined Heat and Power (CHP) ……………………................................................. 28

5.3 Grid Independent Power............................................................................................... 28

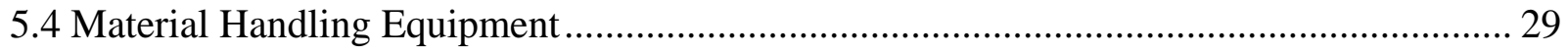


5.5 Small Portable Power .............................................................................................................. 30

5.6 Specialty Vehicles ........................................................................................................... 31

6.0 Strategy Recommendation ............................................................................................. 31

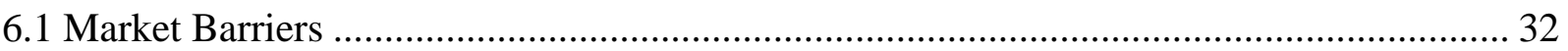

6.2 Recommendations ........................................................................................................... 33

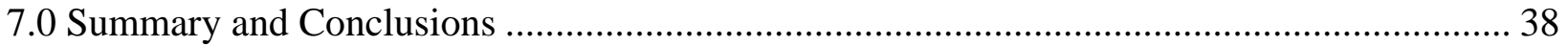

APPENDIX A: CONFERENCES/MEETINGS/WORKSHOPS/SITE VISITS ............................. 41

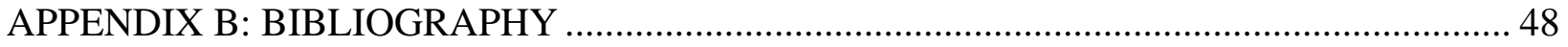

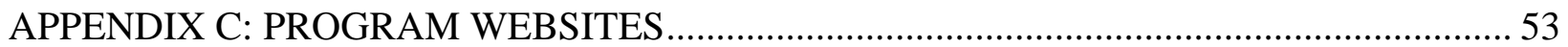

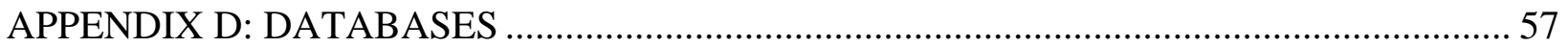




\section{LIST OF ILLUSTRATIONS}

Figure 1. Fuel Cell Applications.....................................................................................

Figure 2. Fuel Cells installed by the Climate Change and Rebates Projects ..............................10

Figure 3. Responses to "If the fuel cell is no longer operational, how many years did it operate?”18

Figure 4. Responses to "What type of application was implemented in your program?"

Figure 5. Responses to "What type of fuel cell was installed?"

Figure 6. Responses to "What percentage of time was the fuel cell available to operate?”..........20

Figure 7. Responses to "How many units are in operation on the site?”

Figure 8. Responses to "How would you rate the availability of infrastructure required to meet your needs?”.

Figure 9. Responses to "How would you describe the cost-effectiveness of the program

(investment vs. market success/failure)?” 


\section{LIST OF TABLES}

Table 1. Classification of Stationary Fuel Cells

Table 2. Protocal for Data Collection....................................................

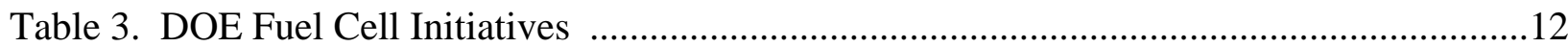

Table 4. DOE’s Market Transformation Projects ........................................................................13 


\subsection{Introduction}

The scientific community is currently experiencing a renewed interest in hydrogen as an energy carrier. The first support for hydrogen began in the 1920s, but interest slipped during WWII. The second wave was initiated by the development of the first practical fuel cell in the late 1950s and continued through the 1960s and 1970s, but again support dwindled in the 1980s after the 1970's energy crisis subsided. In the late 1990s, researchers began to make strong arguments advocating hydrogen as an alternative energy source. The differentiating factor with this current wave of interest is that, unlike the previous two, is that it has gained support from industry, as well as from a continuously growing level of government backing. For example, as part of The Hydrogen Fuel Initiative, the pace of $R \& D$ on hydrogen infrastructure technologies is being accelerated. Currently, government organizations, such as the Department of Energy (DOE) and Department of Transportation (DOT), are researching, developing, and validating hydrogen pathways in order to establish a business case for a hydrogen infrastructure. For example, working with industry, academia, and the national labs, the DOE developed a long-term plan for moving toward widespread implementation of hydrogen technologies [1].

Research from Fuel Cell Today (http://www.fuelcelltoday.com/) has shown there will be substantial growth in the commercial market in years 2009 and 2010. The fuel cell industry as a whole showed a 75\% growth rate in units shipped in 2006-2007. In stationary applications there was an annual growth rate of 125\% between 2005 and 2007 with uninterrupted power supply systems increasing rapidly in terms of sales and distribution. At the time the research was presented, potential outlook showed there will be 12,000 units shipped globally in 2008 and about 30,000 in 2009. There has also been a large jump in interest of fuel cells for material handling vehicles due to recent studies that show them to be economically feasible when compared to traditional equipment used in the material handling sector. Due to this large interest in material handling technology there was an annual growth of 150\% between 2005 and 2007. Niche markets are growing fast in the transportation sector of fuel cell technology with a number of highly successful programs. Portable applications were the first market to support volume shipments, mainly due to their small size when compared to other fuel cell applications. The outlook for portable fuel cell shipments is also the most promising with shipments in the range of 700,000 units expected in 2009 as opposed to just 200,000 units in 2008. 
Fuel cells are a compelling and challenging subject in the field of stationary and portable alternative power applications. The use of hydrogen in fuel cells is more efficient when compared to traditional technology, leading to higher quality of energy with fewer waste products; but, the higher efficiency of fuel cells does not always cover their high initial costs. The purpose of this study is to evaluate both previous and existing fuel cell applications to identify the lessons learned in stationary fuel cell applications. These lessons will be used by future fuel cell applicators for a better initial understanding on how to confront significant obstacles and how to meet the objectives of their planned fuel cell stationary power systems.

\subsection{Summary of Project Methodology}

Over the past two decades, a number of approaches have been used to encourage the application of alternative fuels and related technologies in stationary power generation systems. Most of these approaches have failed because of the lack of a real marketplace, shifts in government policies, and/or the relative lack of interests from industry. Lessons learned with respect to the lack of success and widespread market acceptance of previous alternative fuel technologies, as well as other technologies developed for stationary power systems should be used to provide recommendations for future hydrogen infrastructure and market development strategies. Therefore, this study analyzes different strategies utilized in past and existing power generation systems, performs a critical and encompassing review of literature on existing strategies (implemented or theoretical) for the development of hydrogen infrastructure and markets, and obtains necessary data for development of strategic suggestions.

In addition to literature review and analysis of past projects, information was collected through a brokered protocol, relevant conferences were attended, meetings with fuel cell users were held, and specific fuel cell site visits took place in order to identify the different challenges and opportunities for producing and using hydrogen as an energy carrier. A workshop was help at the 2009 NHA Conference and Hydrogen Expo and an Exhibit was held at the 2009 Fuel Cell Seminar. All of these activities will be discussed in detail later. Information was then compiled and analyzed to gain insight on stationary fuel cell markets, applications, and lessons learned from past and existing installations. 


\subsection{Literature Review}

While the literature on stationary power generation is quite vast, only a select few will be presented here. Baker and Adamson [2] develops a market survey of large stationary applications. Brdar et al. [3] profiles a variety of projects in both manufacturing and service sectors, including the value propositions and objectives. A worldwide analysis is provided that relates drivers, market potentials, and industrial partners. On a regional basis, Nishikawa [4] provides a demonstration of a current large-scale demonstration in Japan, Garibaldi [5] presents a summary of Italian hydrogen parks and projects, and Tulloch [6] outlines a business plan for the Hebridean Hydrogen Park in the UK. Each of these was analyzed for lessons learned during the initial phases of the proposed study. Additional references not discussed here are included in the bibliography.

An identification and characterization of near-term direct hydrogen proton exchange membrane fuels cell markets was completed by Mahadevan et al. [7] under DOE Contract DE-FC3603G013110. In addition, Kurtz et al. [8] are performing analysis of recent DOE activities. These projects should be consulted for additional insights.

\subsection{Fuel Cell Project and Program Identification}

Fuel cell installation databases, such as Fuel Cells Today, Fuel Cells 2000 Database, Roads to Hydrogen Database, and ERDC-CERL Fuel Cell Database were used to identify fuel cell projects around the world. The lessons learned from these programs were used to develop best practices aimed at avoiding repeating the mistakes of prior technology introduction programs through recommendations for a hydrogen strategy, specifically opportunities for hydrogen in stationary power generation systems. Partial listings of project databases and program websites are provided in Appendices $\mathrm{C}$ and $\mathrm{D}$.

A listing of past and existing programs was developed and classified. The main focus was on 5kW to $200 \mathrm{~kW}$ systems, primarily PEM fuel cells, but also with more general technology. The current technology status, i.e., what is currently installed, and applications, were delineated in order to identify lessons learned. The current focus is on stationary power generation, but the interrelationship with the transportation sector should also be understood and will be addressed 
later. In light of recent major technological advances made in fuel cell technology, a framework describing current fuel cell applications was constructed and shown in Figure 1. These classifications will later be used to address lessons learned and recommendations.

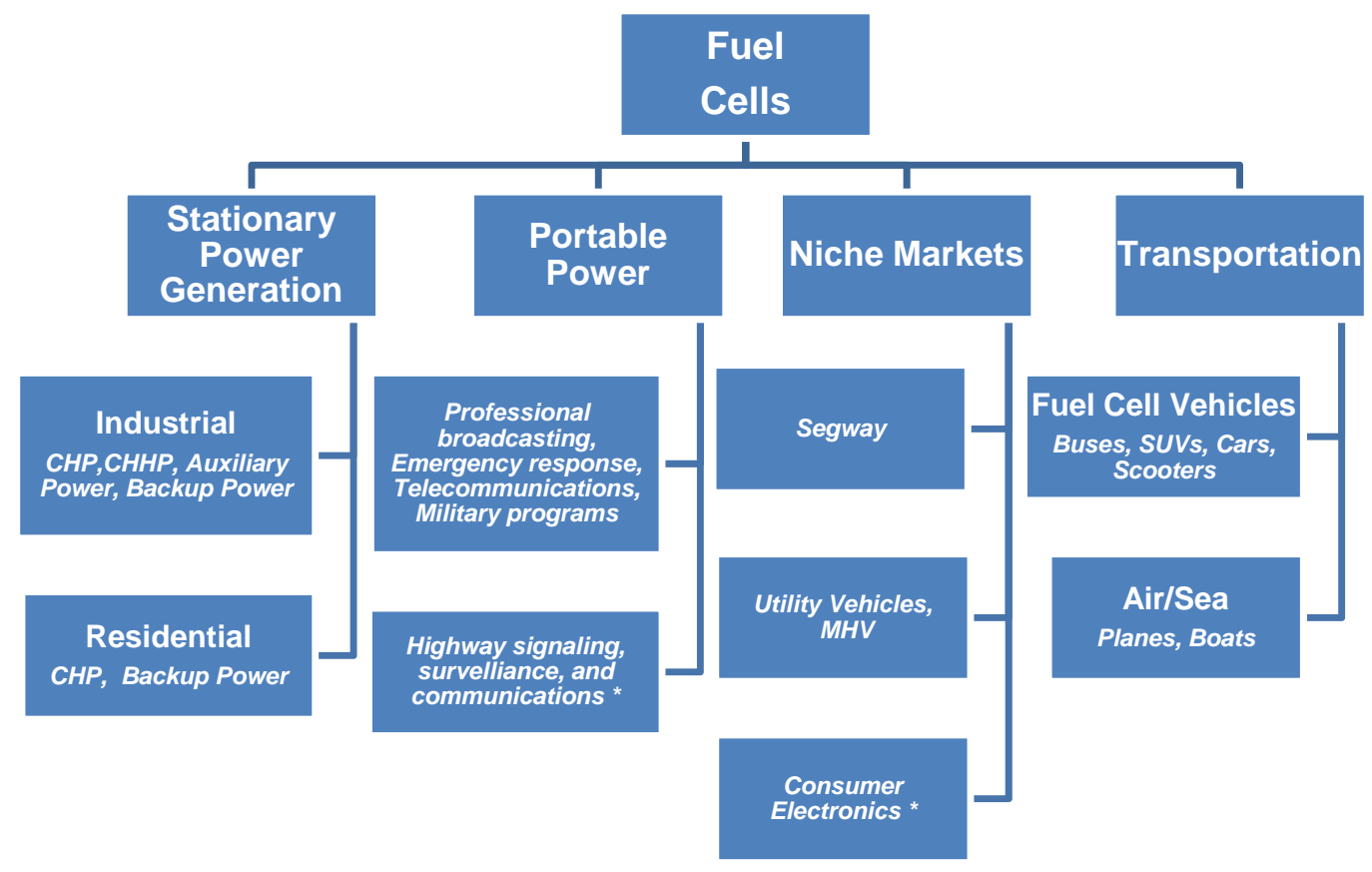

* Fuel cells that do not use hydrogen as fuel

Figure 1. Fuel Cell Applications

Table 1 was tabulated after an exhaustive study of the existing fuel cell installations worldwide and compares the various fuel cell technologies based on initial stationary applications applied to different scales of power requirements. 
Table 1. Classification of Stationary Fuel Cells

\begin{tabular}{|c|c|c|c|c|c|}
\hline & Proton & Phosphoric & \multirow{2}{*}{$\begin{array}{l}\text { Molten } \\
\text { Carbonate } \\
\text { Fuel Cell }\end{array}$} & \multirow{2}{*}{$\begin{array}{l}\text { Alkaline } \\
\text { Fuel Cell }\end{array}$} & \multirow{2}{*}{$\begin{array}{l}\text { Solid Oxide } \\
\text { Fuel Cell }\end{array}$} \\
\hline & $\begin{array}{l}\text { Exchange } \\
\text { Membrane }\end{array}$ & $\begin{array}{ll}\text { Acid } & \text { Fuel } \\
\text { Cell } & \\
\end{array}$ & & & \\
\hline \multirow{3}{*}{$<1 \mathrm{~kW}$} & Power & & & & CHP \\
\hline & CHP & & & & \\
\hline & Testing & & & & \\
\hline \multirow{3}{*}{$1-5 \mathrm{~kW}$} & CHP & Backup & & Backup & $\begin{array}{l}\text { Residential } \\
\text { Power }\end{array}$ \\
\hline & Backup & Testing & & Testing & Testing \\
\hline & MHV & & & & CHP \\
\hline \multirow{4}{*}{$5-250 \mathrm{~kW}$} & $\begin{array}{l}\text { Backup } \\
\text { power }\end{array}$ & Power & CHP & & CHP \\
\hline & $\begin{array}{l}\text { Auxiliary } \\
\text { Power }\end{array}$ & CHP & & & $\begin{array}{l}\text { Commercial } \\
\text { Power }\end{array}$ \\
\hline & CHP & Backup & & & \\
\hline & $\begin{array}{l}\mathrm{H} 2 \\
\text { generation }\end{array}$ & & & & \\
\hline \multirow{2}{*}{$\begin{array}{l}250 \mathrm{~kW}-1 \\
\text { MW }\end{array}$} & & CHP & CHP & & CHP \\
\hline & & & & & \\
\hline$>1 \mathrm{MW}$ & & Power & CHP & & \\
\hline
\end{tabular}

The applications in bold are more common applications, whereas the applications not in bold are applications that are not as common, but are none the less a part of the particular market sector. The table is recommended to be used by potential fuel cell end users to decide if their project can feasibly be powered by current fuel cell technology.

\subsection{Early Market Development Strategies for Stationary Power Generation}

A generic template was created in order to gather general information on past and existing fuel cell projects, and solicited relevant data regarding past and existing stationary and portable fuel cell programs to determine: 
- technology status at the time of introduction,

- strategies used for the introduction of the alternative stationary and portable power technology,

- environmental benefits or impacts,

- overall consumer behavior and attitudes towards to new technology,

- industry participation or lack thereof,

- impact of infrastructure availability,

- cost-effectiveness of the program with respect to the program's overall investment vs. market success or failure,

- description of challenges and how such challenges were approached and overcome, and

- the major achievements of the programs or justification for lack of success.

The data collection consisted of two main components. The first part solicited program information in order to validate the compilation and classification of data (and to make any necessary modifications). The second part specifically solicited projected-related information, including financial status and competitiveness of industry. Respondents were also provided the opportunity to provide additional unsolicited input.

Information was initially gathered through the US Fuel Cell Council and attendees of the 2008 Fuel Cell Seminar. This pool of potential stakeholders was selected to participate because they were the most likely candidates to have had experience with stationary fuel cell powered programs. The primary target audience was end-user fuel cell customers rather than the fuel cell manufactures/suppliers in order to discover the strategies used for the introduction of alternative stationary power technology at the end user level.

Much of the data collection was open-ended in order to solicit personal opinions. Though some data is not quantifiable, it is vital to recognize and understand specific opinions of the end users if accurate judgments are to be made regarding what actions need to be taken and what recommendations need to be made to avoid the complications past users have had to endure. 
Comprised of nine sections, the first section described the study, the next four sections were based around the respondents fuel cell program (mainly quantifiable data to solicit projectedrelated information, including financial status and competitiveness of industry), the next three sections were based around the opinions on fuel cell markets and applications, and the last section asked the respondents to provide optional contact information. The development of each section is discussed briefly in Table 2.

Table 2. Protocol for Data Collection

Part 1: Description. Part One contained explained the study's background information, confidentiality information. It also asked if the respondent is willing to participate in any follow-up data collection.

Part 2: Program Data. Part Two inquired about the date of implementation and location of each fuel cell project, as well as the type of application, manufacturer, fuel, and energy source of the respondent's fuel cell program.

Part 3: Program Data Continued. Part Three was an extension of Part Two that inquired about the available and actual operation time of the fuel cell, the number and size $(\mathrm{kW})$ of units used in operation, co-generation and tri-generation capabilities, and the technology status at the time the fuel cell was introduced.

Part 4: Outcomes. Part Four aimed to gain information regarding the success or failure of the respondents' fuel cell projects. It solicited information related to major achievements of the respondent's fuel cell program, the availability of infrastructure required to meet their needs, and whether the fuel cell project was cost-effective.

Part 5: Lesson Learned. Part 5 aimed to identify the most significant obstacles in the programs and how those obstacles were approache, the general consumer behavior and attitudes toward the fuel cell applications, and the role of codes and standards in the installation.

Part 6: Early Market Applications. Part Six solicited the opinions of the respondent related to early fuel cell markets. Respondents were asked to give their opinion as to what applications are most promising for early market introductions, what role they believed niche markets played in early market applications, and what technological or policy breakthroughs are needed to implement hydrogen applications.

Part 7: Policy Instruments. Part Seven was based around the respondents' opinions of government involvement in the fuel cell industry. In probed what should/can be done related to policy to promote technical R\&D and market competitiveness, and what sort of technical and economic synergies (with, for example, transportation or competing technologies) can be leveraged. In addition, it addressed different government support, initiatives, and tax incentives that were used in the respondents' fuel cell programs. Respondents were also asked whether government support affected their decision to install a fuel cell and whether the installation of a fuel cell was a response to government regulations.

Part 8: Any Additional Info. The respondents were given the option to provide any additional input they might have regarding early market development strategies for stationary power generation.

Part 9: Contact Information. Respondents were also given the option to provide their contact information if they were interested in receiving the results from the study.

Results and conclusions based on the information are provided later.

\subsection{Site Visits/Meetings}


The principle investigator (PI) and co-PIs visited multiple fuel cell installations in order to collect data and lessons learned. Due to the wide range of geographic and climatic areas, this study provided the project with data related to the challenges faced by fuel cell installations at different locations. In addition, face-to-face meetings were held at related events/conferences, and many contacts were made via telephone and email. Specific contacts are omitted due to confidentiality.

\subsection{Workshops and Exhibits}

A Stationary \& Portable Fuel Cell Market Transformation and Applications workshop was held at the NHA Conference and Hydrogen Expo (March 30 - April 3, 2009 in Columbia, South Carolina) to follow-up the preliminary results from the initial data collection and to gather opinions on near-term market hydrogen applications and policy recommendations. About 40 active members of the fuel cell community participated in the workshop and additional data and lessons learned and recommendations were collected during the workshop. The workshop consisted of four presentations describing the potential markets in the fuel cell industry and two break-out sessions. The break out session provided information on the impediments to the fuel cell market and the challenges faced in establishing codes and standards.

A follow-up Exhibit was held at the Fuel Cell Seminar (November 16 - 20, 2009 in Palm Springs, California). The Exhibit allowed for the collection of follow-up information that specifically targeted technical challenges of fuel cell implementation.

\subsection{A Select Listing of Demonstration Projects}

A substantial list of programs, which provides a basis for program data collection, has been identified based on DOE funded projects, as well as other international programs. A significant amount of academic literature, press releases, program announcements, and other related documentation has also been archived.

\subsection{Department of Defense Demonstration Projects}


A significant amount of demonstration projects have been completed by DOD. The related documentation has been collected and listed below:

\section{PAFC Demonstration [9]}

During the demonstration project (1994 to 1997) Phosphoric acid fuel cells (PAFC) were installed at 30 U.S. Department of Defense bases. The objectives of the PAFC Demonstration were to:

- demonstrate fuel cell capabilities in real world situations,

- stimulate growth and economies of scale in the fuel cell industry, and

- determine the role of fuel cells in DOD's long term energy strategy.

U.S. Congress appropriated \$18 million during fiscal year 1993 to advance the use of PAFCs at DOD installations and an additional $\$ 18.75$ million was appropriated in FY94 to expand the program. The fuel cells provided back-up electrical power during power outages and provided heat for boiler make-up water, domestic hot water, space heating, condensate return, process hot water, etc. All the fuel cells were decommissioned between 2001 and 2003 and an estimated annual fuel cell energy savings of $\$ 1,761,000$ was accrued during the performance period of the fuel cells.

\section{Climate Change and Rebate Projects [10]}

Climate Change Fuel Cell Project was established in 1995 from funds appropriated by the Office of the Deputy Under Secretary of Defense, Environmental Security. The overall objective of this project was to expedite the market introduction of fuel cell systems and a total of $\$ 37.5$ million was appropriated under various grants.

The primary benefits of this project include: 
- Enables early adopters to participate in demonstrations and field tests.

- Facilitates manufacturer cost reductions through increased production quantities.

- Encourages financial project support from other supporting agencies.

- Expands options for distributed generation technologies needed to meet growing electricity demand.

The type of fuel cells installed by the Climate Change and Rebate Projects is illustrated graphically in Figure 2.

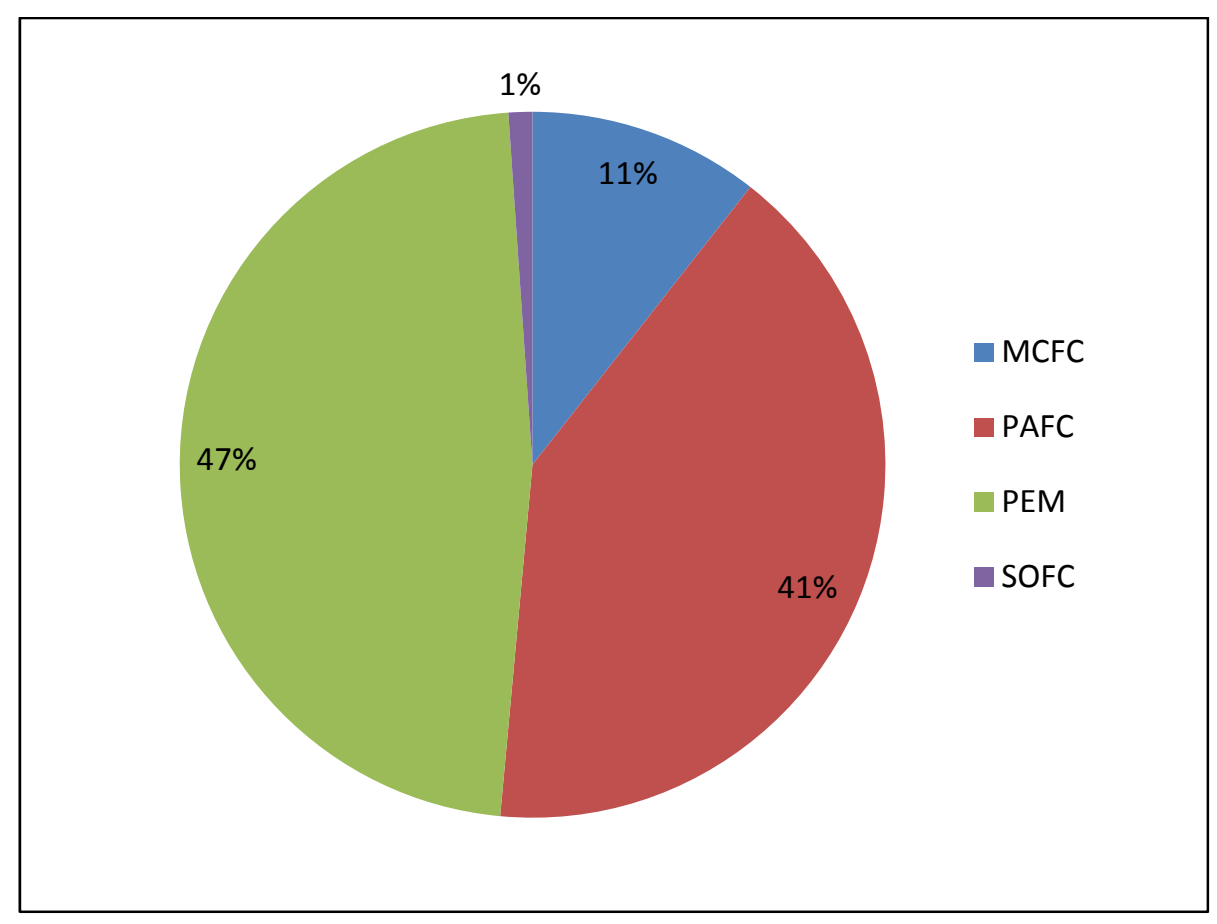

Figure 2. Fuel Cells Installed by the Climate Change and Rebates Projects

A total of 274 fuel cell units were installed during this program of which more than 55\% where $200 \mathrm{~kW}$ or higher.

Residential Demonstration [11-13]

The Department of Defense and US Army Engineer Research \& Development Center Construction Engineering Research Laboratory (ERDC/CERL) demonstrated residential-scale 
Proton Exchange Membrane (PEM) fuel cells at US military facilities in the United States between 2001 and 2006. A total of $\$ 13.7 \mathrm{M}$ of project funding was appropriated by Congress during fiscal years between 2001 and 2004 and completed in 2006. During this period, a total of 22 contractors were selected and 93 PEM fuel cells ranging from $1 \mathrm{~kW}$ to $5 \mathrm{~kW}$ were demonstrated at a total of 56 military sites. Five different fuel cell companies provided PEM fuel cells with power capacity from 1 to $20 \mathrm{~kW}$ during the demonstration. All units were closely monitored to assess their performance, and lessons learned during the demonstration were provided to the fuel cell community to optimize product development and to enhance reliability and performance. The fuel cells logged 530,993 hours of operation with 1,310,193 kWh output and $85.33 \%$ availability.

\section{Recent DOD Initiatives [14]}

As in the case of many new technologies, the military is seen as an effective early adopter. Currently, a number of projects, e.g., 39 fuel cell-powered forklifts (part of an overall Defense Logistics Agency effort) and 18 fuel cell systems that provide backup power to military installations in California and South Carolina are underway, and DOD proposes further deployment of fuel cells for backup power, specialty vehicles, and fuel cell buses. Further, DOD is interested in the portable, scalable, and self-contained generating capability that can be provided by fuel cells for remote and forward installations.

\subsection{Recent Department of Energy Initiatives}

Table 3 is a list of sites recent DOE Initiatives. 
Table 3. DOE Fuel Cell Initiatives [8, 15]

\begin{tabular}{|c|c|}
\hline Location & Description \\
\hline $\begin{array}{l}\text { Fort Lewis, } \\
\text { Washington }\end{array}$ & $\begin{array}{l}\text { This project is in collaboration with DOD/Defense Logistics Agency, fuel cell developers, } \\
\text { hydrogen suppliers and end users. Hydrogen is generated on-site from digester gas and } \\
\text { used to power } 19 \text { fuel cell-powered electric forklifts (using Plug Power class } 1 \\
\text { GenDrive } \\
\text { stationary fuel cell system. }\end{array}$ \\
\hline $\begin{array}{l}\text { Defense } \\
\text { Distribution Depot } \\
\text { San Joaquin, CA }\end{array}$ & $\begin{array}{l}\text { The new hydrogen project at Defense Distribution Depot San Joaquin, CA (DDJC) is } \\
\text { expected start in late } 2010 \text {. This site will get } 20 \text { fuel cell forklifts and will replace the } \\
\text { existing propane forklifts. The fuel cell forklifts will be fueled using hydrogen produced } \\
\text { on-site via electrolysis using solar energy. }\end{array}$ \\
\hline $\begin{array}{l}\text { Barstow MCLB } \\
\text { Backup Power }\end{array}$ & $\begin{array}{l}\text { DOE and DOD worked together to install a four fuel cell system for back-up power } \\
\text { system Marine Corps Logistic Base Barstow (fire station). }\end{array}$ \\
\hline HEB Grocery & $\begin{array}{l}\text { HEB in San Antonio, Texas has purchased } 14 \text { PowerEdge fuel cell systems to power Class } \\
\text { II forklift trucks used at its perishables distribution center, along with the PowerTap }{ }^{\mathrm{TM}} \\
\text { Hydrogen Generator and Hydrogen Station, from Nuvera Fuel Cells. PowerEdge used in } \\
\text { the forklift has a rated power of } 25 \mathrm{~kW}(30 \mathrm{sec}) \text { and has a refueling time of two minutes. }\end{array}$ \\
\hline Sysco & $\begin{array}{l}\text { Sysco of Houston, Texas will deploy } 90 \text { PEM fuel cell systems as battery replacements for } \\
\text { a fleet of pallet trucks at its new distribution center. This installation will be the first ever } \\
\text { green field installation in the world without battery infrastructure for a pallet truck fleet. }\end{array}$ \\
\hline FedEx Missouri & $\begin{array}{l}\text { DOE awarded } \$ 1.3 \text { million in FY09 to deploy } 35 \text { fuel cell lift trucks at FedEx's service } \\
\text { center in Springfield, Missouri. This project will replace the entire fleet of electric lift } \\
\text { trucks with fuel cell lift trucks. }\end{array}$ \\
\hline $\begin{array}{l}\text { GENCO at Coco } \\
\text { Cola }\end{array}$ & $\begin{array}{l}\text { DOE has allotted funds to GENCO Infrastructure Solutions, Inc to purchase } 40 \text { Plug } \\
\text { Power GenDrive }{ }^{\mathrm{TM}} \text { Class-1 fuel cell systems for lift trucks and install supporting } \\
\text { hydrogen infrastructure including hydrogen fueling storage and dispensing system. }\end{array}$ \\
\hline $\begin{array}{l}\text { Defense } \\
\text { Distribution Depot } \\
\text { Warner (DDWG) }\end{array}$ & $\begin{array}{l}\text { Under this project Concurrent Technologies Corporation (CTC) Hydrogenics Corporation } \\
\text { will replace lead acid batteries currently used in Crown Class } 1 \text { lift trucks with } 20 \\
\text { Hydrogenics hydrogen powered Fuel Cell Power Packs. Hydrogen will be produced on } \\
\text { site via natural gas reformation and will also have option for mobile refueling. }\end{array}$ \\
\hline $\begin{array}{l}\text { GENCO Kimberly } \\
\quad \text { Plant }\end{array}$ & $\begin{array}{l}\text { Genco Distribution Systems was awarded federal stimulus funds to deploy } 25 \text { fuel cell lift } \\
\text { trucks as battery replacement of electric lift trucks at the Kimberly Clark plant in } \\
\text { Graniteville, SC. }\end{array}$ \\
\hline $\begin{array}{l}\text { Ft. Jackson Base } \\
\text { Backup Power }\end{array}$ & $\begin{array}{l}\text { Fort Jackson, South Carolina has installed } 10 \text { LOGAN Energy GenSys5C 5kW fuel cell } \\
\text { backup power units to provide backup power to the telecommunications center, energy } \\
\text { monitoring and control facility, and emergency services center. }\end{array}$ \\
\hline $\begin{array}{l}\text { GENCO at } \\
\text { Wegmans }\end{array}$ & $\begin{array}{l}136 \text { Plug Power GenDrive }{ }^{\mathrm{TM}} \text { were deployed at Wegmans distribution center in Pottsville, } \\
\text { PA. }\end{array}$ \\
\hline $\begin{array}{l}\text { GENCO at Whole } \\
\text { Foods }\end{array}$ & $\begin{array}{l}61 \text { Plug Power GenDrive }{ }^{\mathrm{TM}} \text { were deployed at GENCO at Whole foods distribution center } \\
\text { in Landover, MD. }\end{array}$ \\
\hline $\begin{array}{l}\text { Defense } \\
\text { Distribution Depot } \\
\text { Susquehanna } \\
\text { Pennsylvania }\end{array}$ & $\begin{array}{l}\text { The U.S. Department of Energy (DOE) and the Defense Logistics Agency (DLA) will } \\
\text { deploy } 40 \text { fuel cell forklifts at the Department of Defense (DOD) Defense Distribution } \\
\text { Depot (DDSP) in Susquehanna, Pennsylvania. Plug Power (via General Hydrogen) and } \\
\text { Nuvera are supplying the fuel cells to retrofit forklifts while Air Products will provide the } \\
\text { hydrogen fueling station technology infrastructure. }\end{array}$ \\
\hline Plug Power & $\begin{array}{l}\text { Plug Power was awarded a total of } \$ 6.1 \text { million under the American Recovery and } \\
\text { Reinvestment Act funding for fuel cell technology to validate the durability of Plug } \\
\text { Power’s 5-kW stationary combined heat and power fuel cell system and demonstrate the } \\
\text { market viability of the GenCore® rack-mounted fuel cell product. }\end{array}$ \\
\hline Delphi & $\begin{array}{l}\text { DOE has awarded Delphi Automotive } \$ 2.4 \text { million to develop, test, and demonstrate a 3-5 } \\
\text { kW solid oxide fuel cell (SOFC) auxiliary power unit (APU) for heavy duty commercial } \\
\text { Class } 8 \text { trucks. }\end{array}$ \\
\hline
\end{tabular}




\begin{tabular}{|c|l|}
\hline $\begin{array}{c}\text { East Penn's } \\
\text { Manufacturing } \\
\text { Facility }\end{array}$ & $\begin{array}{l}\text { Nuvera will supply } 10 \text { fuel cell forklifts to East Penn's Manufacturing facility in Topton, } \\
\text { PA to accelerate market penetration of fuel cells. }\end{array}$ \\
\hline $\begin{array}{c}\text { Sprint } \\
\text { Communications }\end{array}$ & $\begin{array}{l}\text { Sprint Nextel will demonstrate the viability of packaged 1-kW to 10-kW fuel cell systems } \\
\text { with 72 hours of on-site fuel storage for backup power to communication infrastructure } \\
\text { used by state and local first responders and by public safety answering points (911 } \\
\text { centers). Sprint will address site and permitting issues, and will benchmark the lifecycle } \\
\text { costs, performance, and operational characteristics against the incumbent technologies } \\
\text { (batteries, generators, and diesel fuel). \$7.3 million. }\end{array}$ \\
\hline ReliOn Inc. & $\begin{array}{l}\text { ReliOn will deploy 180 fuel cells with a new refillable 72-hour fuel storage system to } \\
\text { locations across the AT\&T Mobility Network. This will increase reliability to the } \\
\text { communications network at 25 sites throughout central and northern California where } \\
\text { backup power was not available before. }\end{array}$ \\
\hline US Postal Service & 2 fuel cell vehicles used in regular mail delivery service \\
\hline Verizon & A variety of backup systems for network monitoring, availability, and data. \\
\hline
\end{tabular}

DOE is encouraging market transformation by deploying fuel cell projects at various DOE sites and is listed in Table 4.

Table 4. DOE’s Market Transformation Projects [14]

\begin{tabular}{|l|c|c|}
\hline Backup-Power Fuel Cell Deployments & $\begin{array}{c}\text { \# of } \\
\text { Units }\end{array}$ & Total kW \\
\hline Aberdeen, MD & 4 & 20 \\
\hline Adelphi, MD & 4 & 20 \\
\hline DOD/USMC - 29 Palms, CA & 4 & 20 \\
\hline DHS El Centro Sector & 4 & 20 \\
\hline DOD/USAF Cheyenne Mountain & 4 & 20 \\
\hline DHS NY Canadian Border Location & 4 & 20 \\
\hline DOC/NOAA (Maryland Site) & 4 & 20 \\
\hline Fort Bliss, TX & 4 & 20 \\
\hline Fort Bragg, NC & 4 & 20 \\
\hline Fort Drum, NY & 4 & 20 \\
\hline Fort Irwin, CA & 4 & 20 \\
\hline Fort Knox, KY & 4 & 20 \\
\hline Fort Richardson, AK (includes $\mathrm{H}_{2}$ generation) & 4 & 20 \\
\hline $\begin{array}{l}\text { Fort Shaftner, HI / NOAA Co-Location } \\
\text { (includes H generation) }\end{array}$ & 4 & 20 \\
\hline Fort Sill, OK & 4 & 20 \\
\hline Fort Sumter (includes H2 generation via solar electrolysis) & 4 & 20 \\
\hline Huachuca, AZ & 4 & 20 \\
\hline NASA (2 sites) & 4 & 100 \\
\hline Picatinny Arsenal, NJ & 4 & 20 \\
\hline West Point, NY (USMA) (existing H Hnfrastructure) $^{2}$ & & 20 \\
\hline
\end{tabular}




\begin{tabular}{|l|c|c|}
\hline Fuel Cell Bus Deployment Locations & $\begin{array}{c}\text { \# of } \\
\text { Units }\end{array}$ & Total kW \\
\hline Camp Pendleton & 24 & 120 \\
\hline Fort Leonard Wood & 7 & 35 \\
\hline Kilauea Military Camp, HI & 7 & 35 \\
\hline Fort Jackson, SC / Shaw Air Force Base, SC & 24 & 120 \\
\hline Warner Robins, GA & 7 & 35 \\
\hline West Point & 7 & 35 \\
\hline
\end{tabular}

\begin{tabular}{|l|c|c|}
\hline Specialty Vehicle Fuel Cell Deployments & $\begin{array}{c}\# \text { of } \\
\text { Units }\end{array}$ & Total kW \\
\hline USPS - California sites (15 forklifts,7kW per forklift) & 15 & 105 \\
\hline
\end{tabular}

\subsection{International Projects}

As part of on-going efforts, information gathering visits were made to both Japan and South Korea.

Japan [16-17]

The Japanese government, through the Ministry of Economy, and Trade and Industry, demonstrated 76 residential fuel cells between 2002 and 2004 and 480 units from 2005 to prove efficiency, evaluation of environment, an operational method, possible technical problems and solutions, and the system improvement program. The Japanese government leads this project and activates the research and development of the related industries, thus decreasing the cost. Ultimately, they hope to install 120 million units.

\section{South Korea [18]}

As an initial market demonstration study, the South Korean government is operating $2101 \mathrm{~kW}$ PEM fuel cells to evaluate self-confidence, durability, and security of residential fuel cells. In 2006, 40 residential fuel cells were installed for monitoring the proof of technology, followed by 70 additional units in 2007 and 100 additional units in 2008. 
Ten city gas companies were selected and lead the project of residential fuel cell monitoring and proof of technology. They are:

- Central City Gas

- Chungcheong-Namdo City Gas

- Korea City Gas

- Kyongsang-Namdo Energy

- Kyungdong City Gas
- Oceanic City Gas

- Pusan City Gas

- Samchuly City Gas

- Taegu City Gas

- Yesco City Gas

\subsection{Other Fuel Cell Initiatives}

\section{California Stationary Fuel Cell Collaborative [19]}

CaSFCC helps the fuel cell initiatives by developing recommendations for policies and programs that support fuel cell technologies and by working with fuel cell industry, government, and other stakeholders. They have collaborated with other agencies and have installed a 1 megawatt fuel cell power plant at California State University, Northridge and a CHP unit with $500 \mathrm{~kW}$ base load power at TST Inc. in Fontana, California.

\section{New York Power Authority (NYPA) [20-21]}

During this project, 24 Plug Power GenCore ${ }^{\circledR}$ fuel cell systems were deployed across New York State to provide backup power at public safety communications facilities including emergency communication towers that support two-way radio transmissions. The majority of these are $5 \mathrm{~kW}$ fuel cell systems and are capable of providing up to 12 hours of backup runtime. Other NYPA Fuel Cell projects include installation of 21 fuel cells across New York State fueled by either anaerobic digester gas or natural gas and have a total output of over $4500 \mathrm{~kW}$.

\section{First National Bank, Omaha [22]}

This facility uses four UTC PC25 ${ }^{\text {TM }}$ Phosphoric Acid Fuel Cells (PAFC) and provides 99.9999\% available power to computers, chillers and fans opposed to only $99.99 \%$ power by a conventional data center UPS system. 


\section{South Carolina Hydrogen Fuel Cell Alliance [23]}

The South Carolina Hydrogen and Fuel Cell Alliance was founded in January 2006 and consisted of six institutions and organizations dedicated to hydrogen and fuel cell initiatives. Currently the organization includes eight other organizations and work together for the advancement of fuel cell technologies that are cost-effective, convenient, and produced with local resources. They have collaborated with other agencies and have installed stationary fuels and a hydrogen fueling station in South Carolina.

\subsection{Results}

To date, Approximately 100 experts have participated in the study. By acquiring the fuel cell customer/end-user opinion on the current status of the stationary fuel cell market, we have gained knowledge pertaining to what steps need to be taken to make recommendation on how to bring more customers into the fuel cell market. According to the customer, backup power is the most promising fuel cell market for current and future operation. This advances optimism for PEM fuel cells due to their ability to provide reliable backup power for critical load applications such as server rooms or telecommunication towers. Although respondents had a wide variety of opinions based on government involvement, most agreed that more promotion needs to be done through demonstrations, as well as through continuous innovation if stationary fuel cells are going to prove to be a viable opponent to conventional power generation.

According to the respondents, back-up power application is the fuel cell market that seems to be most promising for early market introduction. Reasons for this opinion include the reliability to support critical load systems, proven technology through demonstrations, and electrical efficiency compared to conventional back-up systems. Other applications that respondents were optimistic about were combined heat and power (CHP), material handling, and fleet vehicle applications. The results also show "niche” markets present an important opportunity to bridge the gap from government funded programs to mass market. "Niche” markets are also described to provide adoption potential through established value propositions, as well as through their ability to support higher risks. 
A wide variety of answers were compiled concerning suggestions for early market development strategies, opinions on what actions should be taken regarding policies for promotion of technical $\mathrm{R} \& \mathrm{D}$ and market competitiveness, and suggestions for early market development strategies. According to the experts, there should be more government funded fuel cell grants and programs, rebate programs should be encouraged instead of or in addition to tax credit programs, and there should be aggressive public/private partnerships to underwrite early adopters. Proponents also suggested that if government programs such as DOE were to purchase systems for government applications and sites to prove fuel cell system reliability and potential cost effectiveness then they would be leading the way for industry to follow.

The analysis of the results from the study is a key step in the main goal of developing lessons learned from stationary power generation in regards to a hydrogen fuel cell analysis. The results highlighted in this section are from the initial 82 respondents.

\subsection{Program Data (Parts Two and Three)}

Respondents provided information on how many years had elapsed between initial planning and implementation of the respondent's fuel cell project. It is important to evaluate this duration of time so as to better understand how much time was used for risk analysis, budget management, cost-benefit analysis, and verifying that their site met applicable codes and standards. From information acquired during the NHA workshop, which will be discussed in Section 5, codes and standards play a pivotal role between initial planning and implementation due to the fact that local regulating commissions can delay the building of on-site hydrogen storage. This delay is often due to improper steps taken to ensure the site was up to applicable codes and standards. Of the respondents who were able to answer with confidence, $63.9 \%$ of the respondents stated the time between initial planning and implementation was 2 years or less. This shows quick action was taken to get a large majority of the projects operational and that few obstacles stood between initial planning and actual implementation. Also, from the information acquired, two-thirds of the projects became operational between the years of 2005 and 2008, which shows there has been a large push for fuel cell implementation in recent years. This push is most likely due to factors including support for alternative energy solutions, rising energy costs, and the current mainstream energy production environmental impacts. 
The duration of time in which the fuel cell was in operation is also a critical statistic for this study since initial planning incorporates a significant portion of initial costs. Figure 3 shows that the largest percentage (44.83\%) of the respondent's fuel cell programs are still in operation, which indicates a correlation to a trend of increasing life expectancy of fuel cells. Although the $24.14 \%$ of projects with less than one year of operation seems to point to the contrary, further analysis of the data shows that most of these projects purpose was to prove and demonstrate the concept. Since proof of concepts and demonstrations rarely last longer than one year, it is apparent why $24.14 \%$ of the respondents had a project whose lifespan was within such a timeframe.

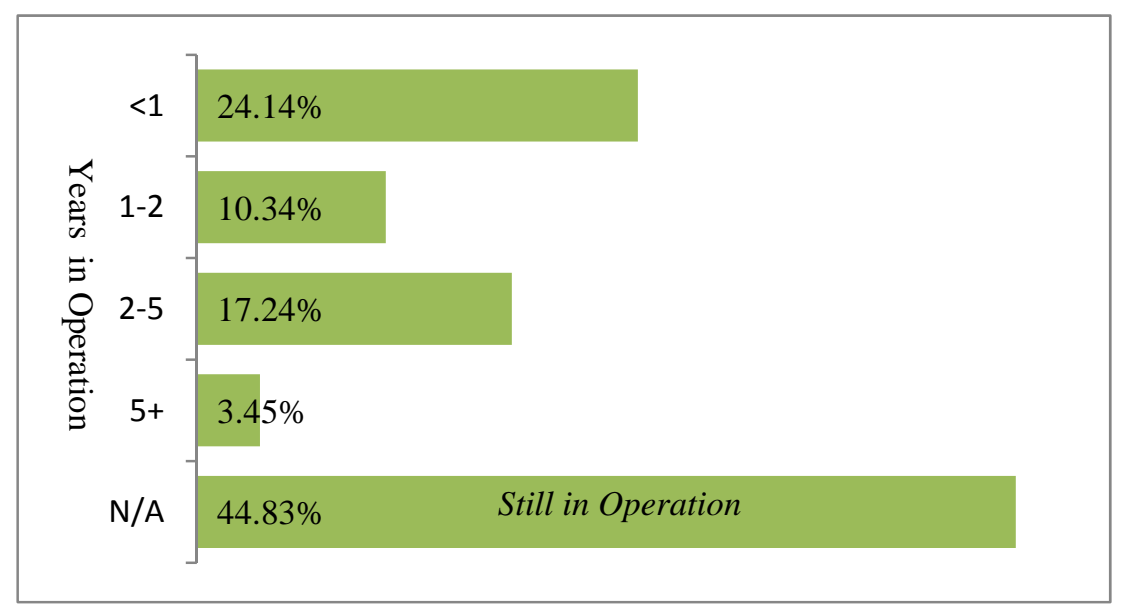

Figure 3. "If the fuel cell is no longer operational, how many years did it operate?"

The leading state represented was California, but there were fuel cell sites located from coast to coast in the United States and also sites located in Canada and Europe.

Information was also collected and discussed related to the types of application implemented in their programs, which type of fuel cell was installed, the fuel cell manufacturer, and what type of fuel was used in the program. Not surprisingly, the vast majority of fuel cell projects were fueled by hydrogen and natural gas, $54.05 \%$ and $24.32 \%$ respectively, with other fuel sources being JP8 (kerosene based Jet Propellant), LPG (Liquefied Petroleum Gas), and methanol. Results show that of those programs which used hydrogen, many used on-site renewable resources such as wind, solar, and biomass. This supports many fuel cell advocates' opinions that suggest hydrogen could be the future for alternative energy stationary power applications. 
The popular types of applications used by the pool of respondents were backup power, material handling equipment, and grid independent power. As shown in Figure 4, backup power is the dominant application used by the respondents.

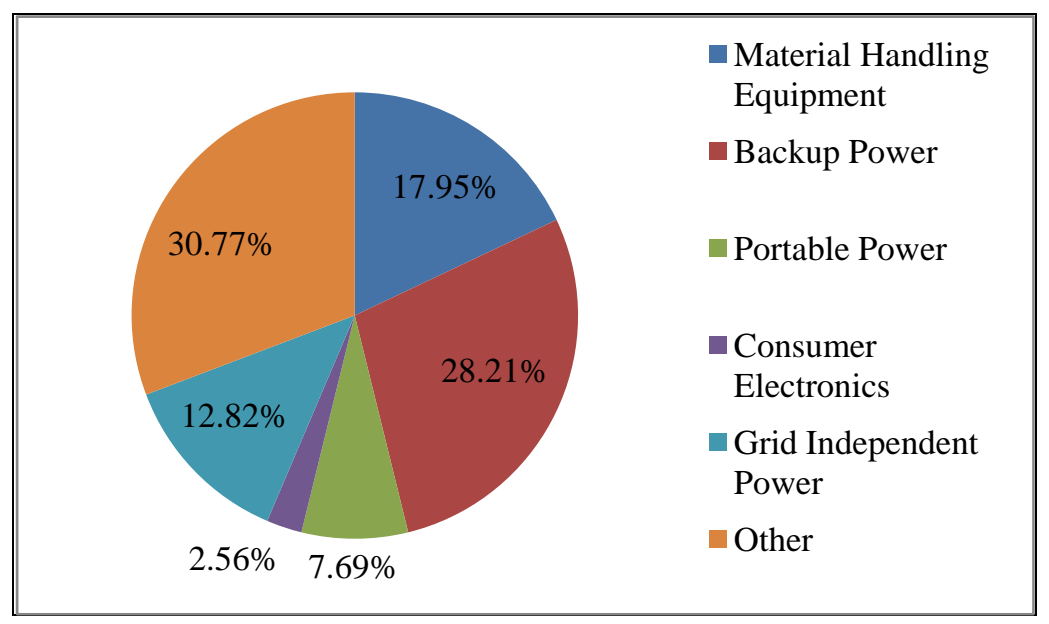

Figure 4. "What type of application was implemented in your program?"

Due to this result, it was not surprising to discover that $66.67 \%$ of the programs used Proton Exchange Membrane (PEM) fuel cells as shown in Figure 5. PEMs are the leading type of fuel cells used in backup power due to their potential to have significant cost advantages over battery and battery-generator systems when run-time capability of up to three days is sufficient [7].

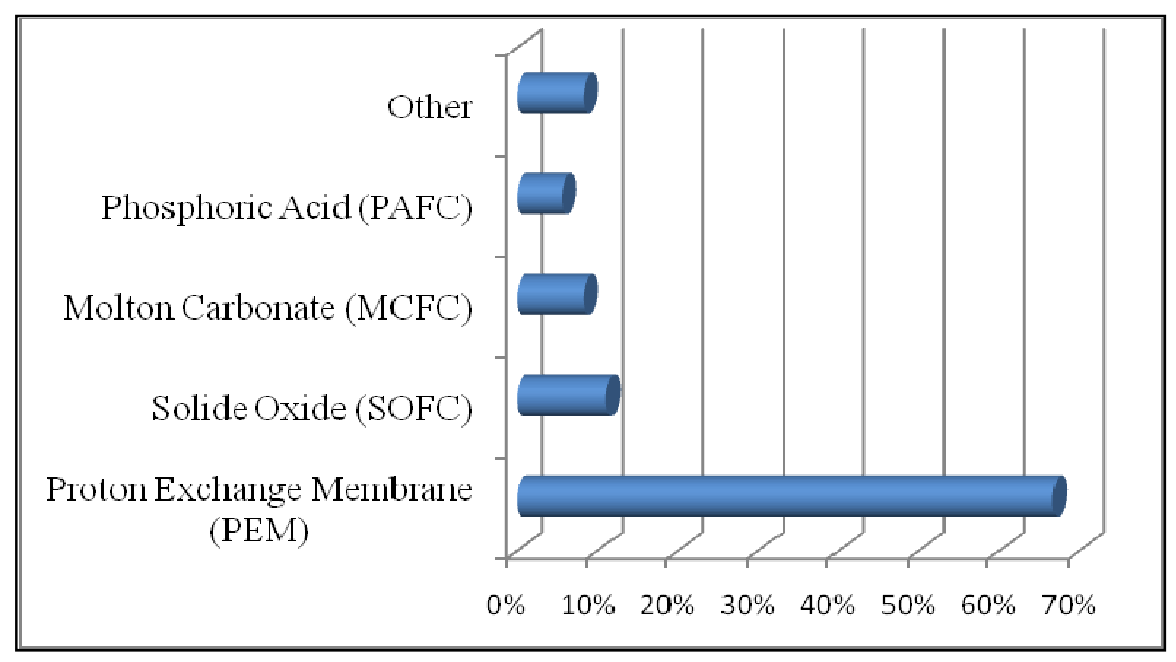

Figure 5. "What type of fuel cell was installed?" 
Intriguingly, of those types of applications shown in Figure 6, 30.77\% were grid connected systems, which encourages optimism for future fuel cell projects that wish to take advantage of grid connected systems and the opportunities they provide for backup power and reliability [24].

Figure 6 shows the percentage of time fuel cell was available to operate. As can be seen in Figure 6, the percentage of time the respondents' fuel cells were available for operation gave mostly optimistic results with $63.3 \%$ being available over $90 \%$ of the project lifetime.

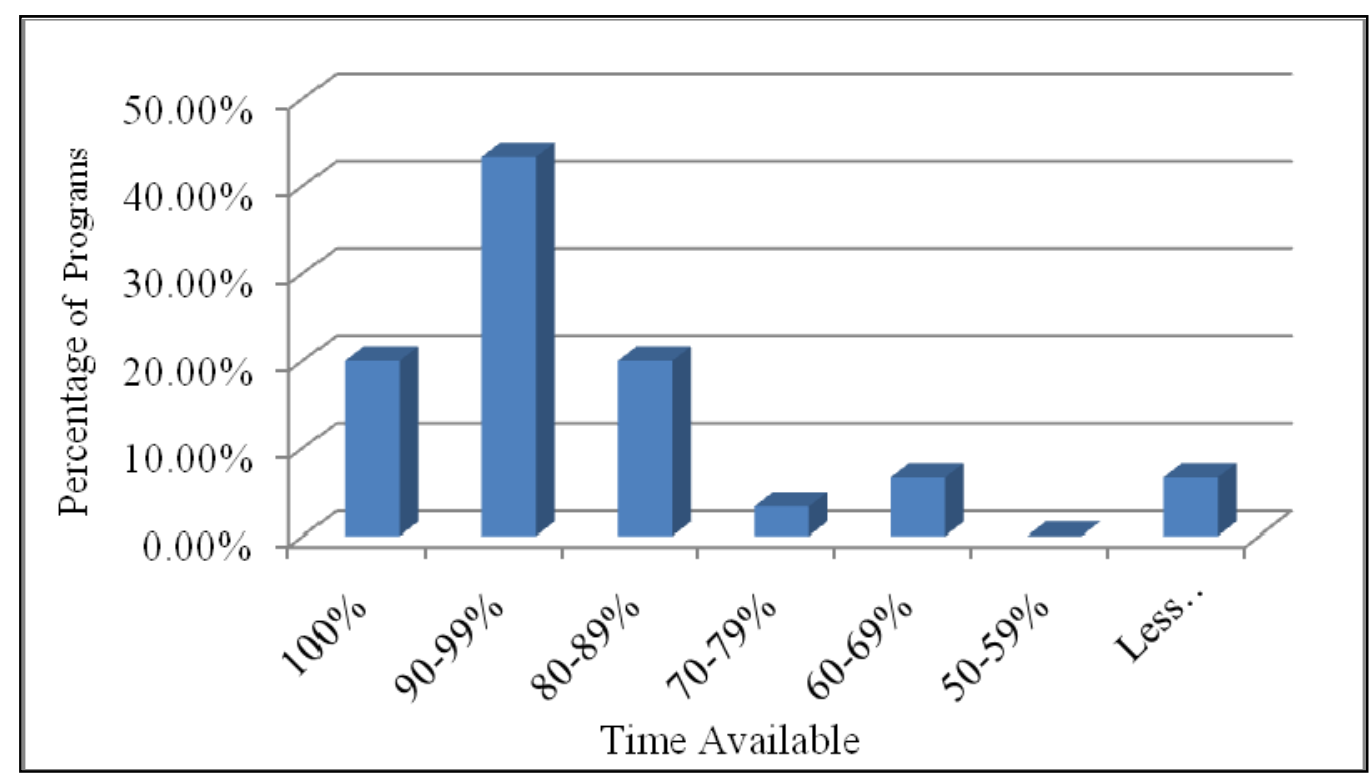

Figure 6. "What percentage of time was the fuel cell available to operate?"

Figure 7 shows how many units were in operation in each fuel cell program. This data ties together both of the previous figures since there is a correlation between PEM fuel cell systems and the normal need for just one unit to operate in backup power and MHV installations. Since the majorities of respondents' applications were PEM fuel cells and were either backup power or MHV, as shown in Figures 4 and Figure 5 respectively, it was not surprising to discover that a $61 \%$ majority of applications needed only one unit to fulfill the programs functionality. 


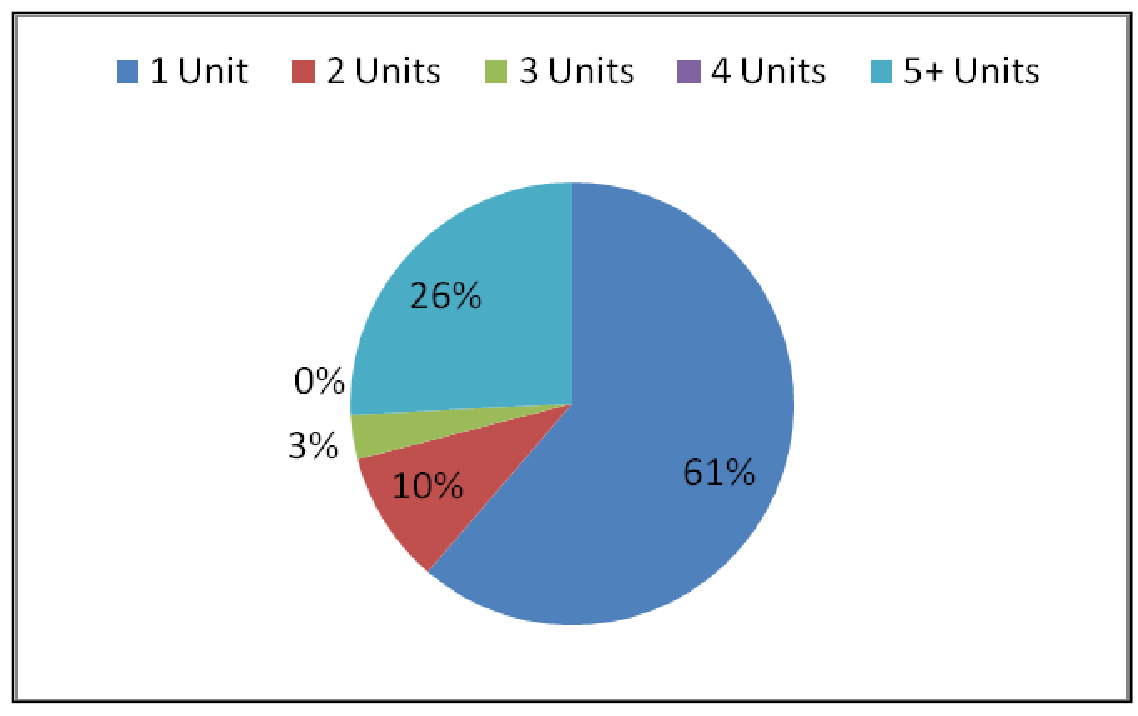

Figure 7. "How many units are in operation on the site?"

Eight of the respondents' fuel cell programs used CHP and only one of the respondents employed a CHHP strategy. Since CHP and CHHP is rarely used in back-up and MHV applications it is apparent why these numbers are so low. Through further analysis of each response it was discovered that the respondents who used fuel cells such as SOFC, MCFC, and PAFC in their program took advantage of the opportunities CHP provides, which is encouraging since it shows that these fuel cells are being used to their full electrical efficiency potential.

The respondents' were also asked to compare their programs to the technology status at the time of introduction. Of the respondents who were able to answer with confidence, $68.0 \%$ stated that their program was considered experimental technology at the time of introduction, with the other 29.0\% and 13.0\% stating their programs were proven technology and state-of-the-art technology, respectively. This shows that many fuel cell customers are willing to take risks with experimental technology.

\subsection{Outcomes (Part Four)}

This section pertains to the overall outcomes of the respondents' fuel cell programs. Figure 8 rates the availability of infrastructure required to meet their needs for the overall system, fuel cells, independent components, and the fuel used. 


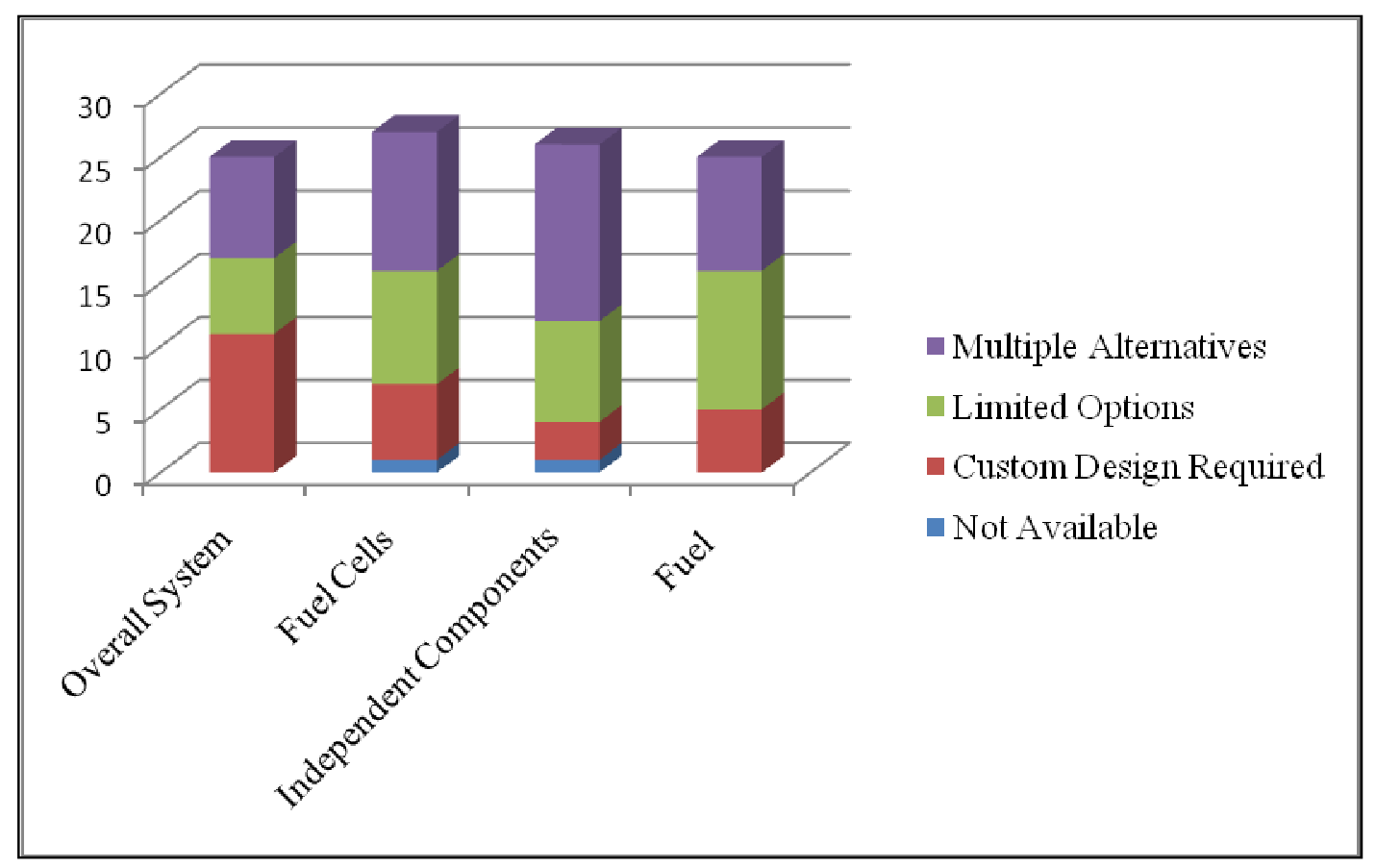

Figure 8. "How would you rate the availability of infrastructure required to meet your needs?"

The largest percentage of respondents said the overall system required custom design. Also shown in the second column of Figure 8 is that, depending on the application used, there was the possibility of multiple alternatives or limited options in regards to using fuel cells. The majority of respondents said there were multiple alternatives for the independent components used in their program, but the majority of respondents were also limited by which fuel could be used.

As shown in Figure 9, the range of answers was wide when the respondents were asked to describe the cost-effectiveness of the program in terms of investment vs. market success/failure. Note that none of the respondents described their program as extremely unsuccessful. 


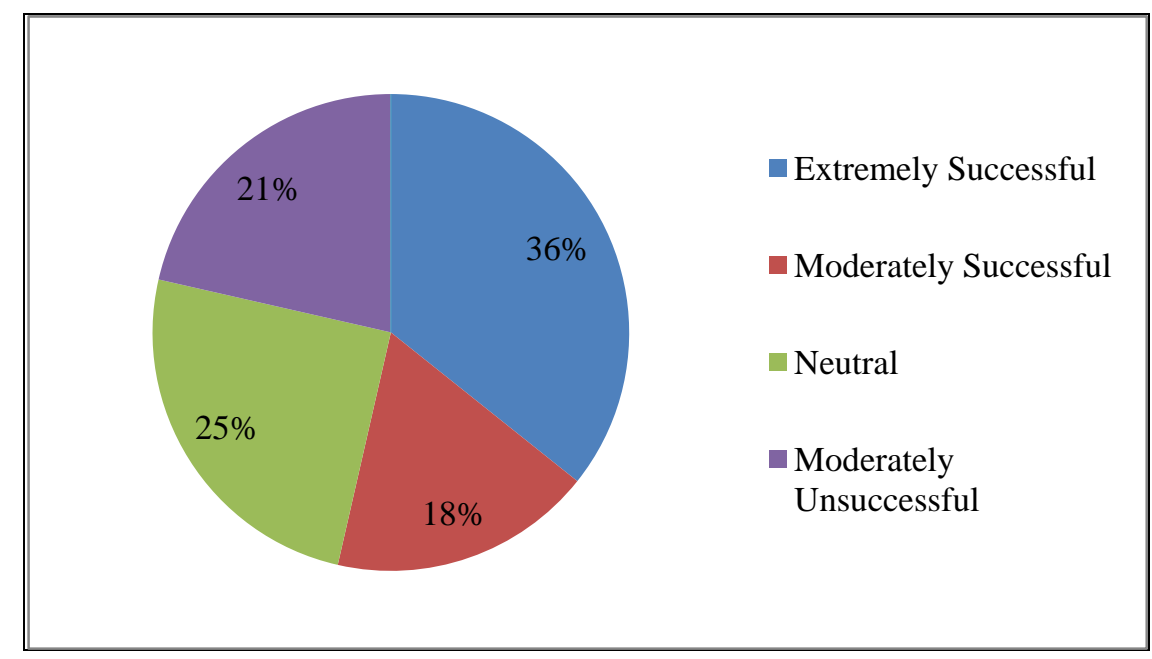

Figure 9. "How would you describe the cost-effectiveness of the program (investment vs. market success/failure)?”

Comparing results shown in Figure 9 to major achievements, respondents who deemed their program a success highlighted that their fuel cells operated excellently without the need for constant maintenance, the high initial costs were subsidized by various government programs, the ability to promote "green" behavior, and the repeatability of their successful demonstrations. The explanations for unsuccessful programs indicate that, despite a success in proving technology, the total investment did not lead to proving the cost effectiveness of the fuel cell solution, high initial investment, and varying regional energy prices. Programs which were in need of constant large scale power for primary power applications discovered problems pertaining to constant fuel cell durability along with significant delays in acquiring spare parts for critical components that failed under operation.

\subsection{Lessons Learned (Part Five)}

Respondents described the most significant obstacles in the applications and how those obstacles were approached, and what role codes and standards played in the installation process. (Consumer behavior and attitudes are not discussed since the answers strongly correlate with the study done by Ricci et al. [25].) Best practices for possible obstacles include the following.

- A ready supply of spare parts for parts prone to breaking down should be kept in stock due to the amount of time it takes to receive spare parts on a moment's notice. 
- The use of alternative energy tax cuts should be leveraged to reduce overall cost of fuel cell project.

- For on-site hydrogen storage installations, consult the local fire marshal early in the planning stage to alleviate codes and standards complications that may arise in the installation phase.

\subsection{Early Market Applications (Part Six)}

According to the respondents, backup power, MHV, and CHP are the most promising fuel cell markets for current and future operation. Reasons for this opinion include the reliability to support critical load systems, already proven technology through demonstrations, and electrical efficiency compared to conventional systems. This advances optimism for PEM fuel cells due to their ability to provide reliable backup power for critical load applications, e.g., server rooms or telecommunication towers, and their dominant role in the MHV market. Many respondents believe niche markets to be very important to early market applications. Niche markets are also described to provide adoption potential through established value propositions, as well as their ability to support higher risks. Best practices for niche markets include the following.

- Use niche markets to show a value proposition for fuel cell adoption.

- Niche markets can be used to demonstrate feasibility in hopes of bringing down the manufacturing cost curve.

- Military can be leveraged in niche markets as it has been successfully leveraged in the past for early market development (e.g., GPS units and the Internet).

Technological (or policy) breakthroughs that are needed to implement hydrogen applications and suggestions for early market development strategies were also discussed. Results show that there needs to be breakthroughs in hydrogen storage and infrastructure for there to be a feasible push for hydrogen as a dominant energy carrier in the near future.

\subsection{Policy Instruments (Part Seven)}

Regarding early market development strategies, results indicated that there should be more government funded fuel cell grants and programs, rebate programs should be encouraged instead 
of, or in addition to, tax credit programs, and there should be aggressive public/private partnerships to underwrite early adopters. Proponents also suggested that if government programs, such as DOE, were to purchase systems for government sites to prove fuel cell system reliability and potential cost effectiveness then they would be leading the way for others to follow.

The majority of respondents believed that the transportation sector could be leveraged for the stationary sector if the use of hydrogen in the transportation sector were to become a mass market application. A reason for this opinion is due to the belief that if hydrogen was a popular fuel for transportation then a hydrogen infrastructure would then already be in place for the stationary sector to use to its advantage. Additional data show that a vast majority of $84.6 \%$ of our respondents believe other developments, such as "green" technologies, are an incentive to hydrogen technologies rather than an impediment.

A consolidation of the recommendations for what government agencies can do to help create markets is shown below.

- The DOE needs to create public/private partnerships with incentives.

- Develop nationally accepted codes and standards.

- Continue to offer hydrogen training to local fire marshals and building officials, which will help minimize the mystique of hydrogen technology.

Most respondents said their program was financially supported by some sort of government funding to offset costs; $72.7 \%$ indicate that this support positively affected their decision to implement a fuel cell project.

Only one of the respondents said his/her program was in response to government regulations, whereas all others said the installation of a fuel cell was part of a corporate initiative. This supports the growing number of corporations who are beginning to implement alternative energy efforts in response to the current public opinion of the world's irresponsible energy usage. 


\subsection{Workshop Results - Stationary \& Portable Fuel Cell Market Transformation and Applications}

A workshop on "Stationary \& Portable Fuel Cell Market Transformation and Applications" was hosted at the NHA Annual Conference and Hydrogen Exposition, April 2, 2009 in Columbia, South Carolina, to address applications and options for transformation of stationary and portable fuel cell markets. Highlights of the study provided a background for discussion on related issues. Panelists from the Missouri University of Science and Technology, US DOE Hydrogen Program, and other interested organizations provided brief presentations and lead small breakout discussions. The workshop was held with approximately 40 participants.

During the workshop, the fuel cell and hydrogen application group held an in-depth discussion on why certain fuel cell applications were starting to gain ground in the marketplace while others were either not gaining ground or falling back in the market. Not surprisingly, the rise of sales in the backup power (especially in the telecommunication/radio tower market) and the material handling vehicle (MHV) sectors were credited to the fact that these two applications have recently proven to be more efficient in regard to both electrical efficiency and cost effectiveness when compared to traditional technology. Advantages and lessons learned from these two specific fuel cell applications provide additional insight as to why these fuel cell technologies have become the front-runners in the attempts for mass market penetration.

Insight from the workshop was incorporated with the other analyses on an application-specific basis as described below. An exhibit was held at the Fuel Cell Seminar and Exposition, November 16-20, 2009 in Palm Springs, California, for further validation and to solicit additional project data and discussions with exhibitors and patrons.

\subsection{Backup Power/UPS}

Fuel cells used in backup power for telecommunication/radio towers, or any other technology that requires completely uninterrupted power, have proven to have a large number of benefits when compared to incumbent technology. Fuel cells have a faster start up time when compared to on-site generators, and prove to be cost efficient when compared to standard VLRA battery systems when used in combination with a bridged battery system to provide power between grid 
shutdown and fuel cell startup. Fuel cells used in backup power applications can also be remotely monitored and require less maintenance.

Often, monitoring systems were needed due to the security shut down feature within most fuel cell system. The system would automatically shutdown if there was a change in the performance characteristic of the fuel cell or any other operational anomaly. Remote monitoring systems could monitor the performance and operation of the fuel cell and could prevent it from unnecessary shutting down due to external factors or/and could prevent damage to the system during a major event. For example, operation of fuel cells (located outdoors) during winter was a source of major concern in many cases. It was observed that the fuel cell had to run at a minimum capacity or had to be provided with an external heated enclosure to avoid freezing of the fuel cell membranes. As for the fuel cell that was not used continuously, energy to keep the fuel cell warm during winter operation was high. Fuel starvation was another major problem during the fuel cell operation.

The fuel cell market has not reached mass production and often is manufactured to order. As a result, spare parts are not readily available and often have long lead times. This interferes with the fuel cell operation and, therefore, other backup solutions have to be provided for the operation of the facility requiring backup power. In order to mitigate this problem, steps should be taken for the fuel cell components to be easily and readily available. Lessons learned from backup power/UPS are summarized below.

- Requires less maintenance than generators due to the lack of moving parts.

- A recent Battelle study shows PEM fuel cell are cost effective when backup runtime is less than 72 hours [7].

- Energy is needed to keep the fuel cell warm in the winter and fuel starvation is a major challenge in very harsh climates.

- Integration of the pressurized electrolyzer with the hydrogen and oxygen storage units is not straightforward due to slightly different tank pressures [26].

- Power produced by fuel cell is costly when it is fueled by hydrogen produced from grid electricity. 
Most of the backup power applications used either industrial grade hydrogen from cylinders or on-site hydrogen produced through electrolysis to run the fuel cell. It was noted that the cost of power was about $\$ 4.00 / \mathrm{kWh}$ when the fuel cell was fueled by hydrogen produced from grid electricity. Hence, it was evident that on-site hydrogen production should be encouraged using renewable sources especially at locations using PEM fuel cells.

\subsection{Combined Heat and Power (CHP)}

Aside from the fact that CHP fuel cell applications are considered "green", they also have the highest electrical efficiency when compared to any other application in the market today. Other reasons for potential customer's consideration of CHP to provide either secondary or primary power are the unstable gas and oil markets and the dramatically rising grid electric costs. Also, the recent financial crisis has shown just how unpredictable markets for the near future can be. Bompard et al. [27] points out that using fuel cells for residential power is still in its infancy in regard to becoming cost effective. However, the lessons learned from previous CHP applications will prove to be very valuable to potential CHP operators and customers, and are as follows.

- Installation and commissioning of CHP projects usually take longer than expected.

- The development of pre-packaged, pre-engineered systems may advance the market more quickly.

- Provides a good economic fit between offsetting electrical loads and meeting on-site thermal needs.

From the workshop, the policies group concluded that although natural gas is not a renewable resource, the increased efficiency of fuel cell CHP systems can enable significant energy savings when using the natural gas reforming process. The energy benefits derived from the higher efficiency of fuel cells needs to be rewarded in a better way through policy in order to help increase the penetration rate.

\subsection{Grid Independent Power}

This category primarily comprises fuel cells capable of producing more than $50 \mathrm{~kW}$ power and are mainly SOFC, MCFC, or PAFC. These fuel cells take natural gas or anaerobic gas available on-site and reform it to hydrogen to supply the fuel cell stack. Power generation was often 
accompanied by heat and hydrogen production and required plant components that are appropriately sized for the specific site. These were custom components for the site and the necessary reliability was difficult, sometimes impossible to obtain. Steps should be taken to mitigate these situations and make these fuel cell components easily and readily available. Another important problem encountered during the operation of grid independent power application was the high cost of the power produced, which depended of the natural gas price in the region.

Grid independent power is not usually cost efficient when compared to the cost of standard utility options, except in remote and inaccessible locations where grid extension is very costly [28]. The main purpose and reason for such high costs is due to the fact that it is completely independent of the standard power grid and is therefore unaffected by grid fluctuations and downtimes. Regardless of the lack of cost effectiveness, there are still lessons to be learned from previous installations.

- Effective, but costly, way of meeting new environmental emission codes and standards.

- Viable if the electrical load is ultra sensitive to standard utility voltage fluctuations.

\subsection{Material Handling Equipment}

Material handling fuel cell applications have multiple advantages as compared to traditional battery operated material handling equipment. Fuel cells used in the material handling sector have no degradation of power during their time of use due to the fuel cells ability to maintain constant power as long as fuel is still being supplied to the stack. There is a large amount of reduced downtime during the refueling process since battery operated equipment takes a much longer time to recharge than fuel cell hydrogen tanks take to refill. Coinciding with reduced downtime is the potential for increased productivity in operations that require multiple shifts per day. 
For material handling purposes, hydrogen fuel cells are economically feasible only if there is a 24 hour shift requiring replacement of batteries and fast filling. For an 8-12 hour operation per day, batteries are a more viable option than a fuel cell.

- Workers must be retrained to operate fuel cell equipment due to changes in standard safety protocol.

- Allows for rapid refueling (few minutes instead of multiple hours).

- No degradation of power over usage time. (i.e., fuel cells provide constant power without voltage drop until hydrogen is completely depleted).

- Drivers ran out of hydrogen since there is no power degradation to indicate remaining runtime.

- Hydrogen fuel cells are beneficial in both cost effectiveness and increased productivity if there is non-stop operation (i.e., three eight hour shifts) [7].

A complete analysis of fuel cell forklifts is provided in [29].

\subsection{Small Portable Power}

The portable and consumer electronics sector also has benefits that provide potential leverage over incumbent technology. Consumers are constantly demanding that more features be included with their small electronics and with those features there is a need for longer runtimes and higher power output. Fuel cells used in consumer electronics provide longer runtimes with higher power output. They also weigh less than standard batteries, which is an advantage especially in the laptop sector of the consumer electronics market. Portable fuel cells have the advantage of outputting very little noise while in operation, a necessity in applications such as military missions.

This is a sector of the fuel cell market that has great potential, especially for use in the military. With the growing need for electrical power for military missions, the total weight of power sources to be carried along on a mission is ever increasing. Agnolucci [30] and Kamarudin [31] further discusses these benefits. The lessons learned from these applications are listed below.

- Fuel cells are much lighter than generators or batteries. 
- Create a noise free electrical power source.

- Continuous power supply; eliminates the necessity of having to interrupt the mission for battery recharge.

The portable fuel cell market has not shown a large amount of growth due to high costs when compared to incumbent technologies. As with stationary applications, further R\&D is needed. It is recommended that the military be leveraged to show the advantages of fuel cells. Fuel cells are much lighter than battery/generator applications and emit very low amounts of noise. In the past, the military has been used as a catalyst for future mass market penetration. For example, GPS units were adopted by the military despite their high costs; due to the advancements made through the support of the government they were introduced to the mass market at a lower cost. This case can also be made for the advancement of fuel cells in portable applications.

\subsection{Specialty Vehicles}

Another small sector of portable power is in the domain of specialty vehicles (e.g., airport baggage trucks, utility vehicles, and personnel transporters). There are a few installations that utilize the advantages of such applications but they have yet to prove to be cost effective when compared to the traditional equipment used for such functions. The lessons learned from these few installations are mainly based around publicity and are listed below.

- Convenient mode of transportation.

- Provide publicity for using alternative/renewable energy for power.

- Can be used to educate the public about hydrogen fuel cell technology.

\subsection{Strategy Recommendation}

Market penetration is the ultimate goal of any new technology. Though the stationary fuel cell market has been steadily increasing around the world, there are still large obstacles impeding the path to large market penetration. Thus, fuel cell technology still faces an uphill battle toward mass penetration. Breakthroughs will be possible when a variety of market barriers are overcome. 


\subsection{Market Barriers}

Dwyer and Tanner [32] stated that "barriers to entry are the obstacles a potential entrant must overcome in order to compete in the market.” The barrier to entry for stationary and portable fuel cell technology include a variety of technical and socio-economic/political barriers. Thus, broader metrics for whether an early market is strategically aligned must be considered.

\section{Technical Considerations}

Though even with large amounts of support for fuel cells there is still a need for more technical research and development in most all of these applications. Much data needs to be collected and shared in order to validate technology. Durability and reliability of components e.g., improvement in PEM stacks, balance of power (such as sensors, pumps, reformers and energy converters), must be addressed in experimental and applied environments. Among others, fuel reformation, hydrogen safety, readiness of infrastructure, and $\mathrm{CO}_{2}$ sequestration issues, as applicable, must be considered. Additionally, increased support for R\&D in hydrogen storage technologies would address a leading cost factor in middle to large scale fuel cell applications (10kw - $1 \mathrm{MW}$ ), as well as address renewable infrastructure. The 2011 DOE targets for stationary fuel cells are durability of $\mathbf{4 0 , 0 0 0}$ hours, and efficiency (fuel to electrical including reforming) of $\mathbf{4 0 \%}$.

\section{Cost Competitiveness}

Clearly, one of the main obstacles to market penetration is the high initial costs associated with stationary fuel cell applications. Market penetration of the PEM fuel cell will only be possible when both capital and installation cost for fuel cell decreases and becomes more competitive with other power sources. The 2011 DOE target for stationary fuel cells is $\$ 750 / \mathbf{k W}$.

\section{Fuel Flexibility}

One critical lesson gathered is that fuel cells are able to operate on a wide range of fuel inputs; hence their role tends to be a bridge between technologies of current fossil fuels and a future hydrogen economy. In other words, hydrogen fuel cell technology must be a stepping stone to a future hydrogen economy, as they have yet to prove to be a standalone solution. Fuel flexibility 
is also important when major fuel sources such as hydrogen are not available, thus infrastructure development is also a barrier.

\section{Public Acceptance}

Many consumers who are unfamiliar with hydrogen technology believe that hydrogen is unsafe for use by the average citizen. The public must be made aware that hydrogen is not only safe, but has also proven to be cost effective in many applications in the mass market. If a large majority of the public no longer felt that hydrogen technology is unsafe, then the fostering of innovative government policy would be less cumbersome. Public-Private Partnerships may provide the opportunity for more efficient project management, proficient risk mitigation, and enhanced technological innovation.

\subsection{Recommendations}

Recommendations to address these concerns range from incentives to additional research to unique systems development.

\section{Continue Demonstration Projects}

One of the main challenges that must be addressed to increase the commercial viability and market penetration of all types of fuel cell applications is consumer awareness. The public is still not aware of the almost limitless potential fuel cells possess. The public should be educated as to the ways fuel cells could enhance their everyday lives; whether it is by powering a laptop for an extended amount of time as opposed to regular battery packs or through reducing dependence on foreign oil with the incorporation of fuel cell vehicles. Demonstration of technology is a key step in the right direction.

According to the suggestions of fuel cell industry leaders and end users, government agencies should set an example and lead investment in clean technology. Most of them see fuel cell 
applications as successful in proving the technology, but cannot prove the cost effectiveness of the fuel cell solution. During the project it was noted that fuel cell applications at military installations were highly successful and should be targeted as early adopters. Government agencies, including the military, can even be used as a market catalyst and would be ideal as the early adopters of stationary and portable power systems. Many technological devices such as GPS and the internet have first been successfully adopted and refined by the military, followed by huge demand in the civilian market sector. Additional targets for demonstration projects include educational facilities and health care facilities as well as, of course, energy.

\section{Application Specific Competition}

There is early market support for fuel cells in various stationary and portable applications including: small consumer electronics, residential and commercial backup power, portable power, CHP (Combined Heat and Power), material handling equipment, specialty vehicles and complete grid independent power. In addition to environmental benefits, fuel cells have many advantages over incumbent technology in many of these applications. Most individuals who are not educated in fuel cell technology only associate fuel cells with the transportation sector, which is also a promising fuel cell application, but will most likely not be the first fuel cell application to penetrate the mass market. Thus, there should be a balance between near term and long term applications.

Fuel cell applications which have already proven to be reliable and viable are material handling equipment (forklifts and airport baggage transporters), backup power, and combined heat and power (CHP) applications. Material handling equipment has set itself apart due to its ability to have centralized fueling, but it has only proven to be cost effective with high utilization. Backup power (generally $5 \mathrm{~kW}-20 \mathrm{~kW}$ ) has also been demonstrated with relative success in regards to reliability. With electrical efficiency reaching $80-90 \%$, CHP fuel cell applications can be an excellent solution for controlling energy costs while improving the reliability of power and thermal energy supplies since CHP provides a good economic fit between offsetting electrical loads and meeting on-site thermal needs. Combined Heat and Power (CHP) and Combined Heat Hydrogen and Power (CHHP) should be considered viable early market fuel cell applications, and are discussed further related to a later recommendation. 


\section{Tax Credits/Subsidies}

Tax credits and other financial aid to the fuel cell industry have played a major part in the success of fuel cell projects. Therefore, one recommendation is to continue to provide tax credits, loan guarantees, and other financial aid as further incentive to potential customers to use hydrogen fuel cells in their stationary and portable power applications. An increase in alternative energy tax credits and/or the implementation of alternative energy subsidies is recommended in order to reduce the overall cost of the fuel cell project. These subsidies can be justified by a fuel cell application's ability to reduce carbon and other airborne emissions, reduce overall waste, increase reliability, operate more quietly, and promote alternative energy technology advancement. Again, Public-Private Partnerships may provide for innovative financing options.

Individual investors will not likely benefit much from federal tax credits due to the alternative minimum tax (AMT) and passive activity loss (PAL) limits. So large publicly held, taxable, CCorporations would make the ideal tax investor since they have a partial sensitivity to how investment affects their financial statements. Again, Public-Private Partnerships may be ideal for developing relationships to address these issues.

Ironically, a special rule in Energy Tax Credit policy, stating that no energy tax credit applies to qualified fuel cell property that is used predominantly in the trade or business of the furnishing or sale of telephone service, telegraph service by means of domestic telegraph operations, or other telegraph services., is a major drawback to fuel cells in backup power applications since telecommunications towers are a large potential market.

\section{Focus R\&D Efforts}

As mentioned, R\&D efforts must focus on demonstrating that cost, durability, and reliability can be met for early markets. Hydrogen fuel cell technology constitutes a highly interdisciplinary field that extends from the fundamentals of materials, electrochemical processes, and fuel processing/storage systems, to complex design concepts for hybrid vehicles, and renewable power/fuel systems. Also, infrastructure analysis, market transformation, public policy, safety and environment play key roles. Additionally, sustainable energy systems is an emerging field 
that aims to develop new and improved energy technologies, systems, and services, while understanding the impact of energy on the economy and society. The topics are connected through the sourcing, production, distribution, storage, and utilization of hydrogen technologies.

The hydrogen supply network must be modeled and analyzed, including system infrastructure and economical/political considerations that include the dynamics of a myriad of potential combinations of production technologies and delivery methods, many of which vary in appeal based on regional considerations. Research is needed to accurately predict hydrogen demand growth based on intrinsic and extrinsic factors such as stationary and portable applications, hydrogen vehicle penetration rates, renewable-hydrogen systems, and other considerations. Incorporating these outcomes will be required to determine the optimal timing of the introduction of hydrogen infrastructure components, e.g., production, storage, or distribution.

\section{Target Niche Markets}

Niche markets are also described to provide adoption potential through established value propositions, as well as their ability to support higher risks. For successful early market penetration of PEM fuel cells, niche markets such as farms, remote power, wireless telecommunication towers, and utility vehicles should be considered. Niche markets can be used to demonstrate feasibility in hopes of bringing down the manufacturing cost curve. And, as with other applications, the military and other government entities can be successfully leveraged. National parks also provide excellent demonstrations of these niche applications.

\section{Integrated Systems}

Integrated systems such as using wind, solar, and hydro power to create hydrogen are encouraged to be used whenever feasible due to their ability to create hydrogen from renewable sources. Nuclear hydrogen systems should also be considered. CHHP (Combined, Heat, Hydrogen, and Power) systems are recommended to bridge the gap between traditional and alternative approaches. Using CHHP increases efficiency and can be used to level up intermittent renewables. An additional advantage is that CHHP provides an opportunity of serving the market transition by generating hydrogen on-site. Fuel cells in conjunction with renewable-hydrogen fuel cell systems and transportation systems would also lead to long-term employment growth, 
but would have less effect in the near-term. Similarly, look of Synergies with transportation by focusing on early market applications that share attributes with transportation, e.g., operational modes, supply chains, and fuels. In urban area, the hydrogen fuel stations may be a realistic opportunity for market penetration.

Integrated renewable-hydrogen systems could be considered a mid-term, low-volume application of fuel cells as hydrogen provides a pathway for the expanded use of domestically produced intermittent renewables. Since the electricity generated from renewable sources such as wind, solar, and hydro can be turned into hydrogen and stored until it is needed as fuel for either stationary, portable, or transportation applications, or transferred back into electricity and fed into the electrical power grid, renewable hydrogen systems should be considered when addressing fueling and infrastructure for other applications. Particularly, if on-site hydrogen production is a necessity in the fuel cell project, use of renewable energy (e.g., solar and wind) is recommended, especially at locations using PEM fuel cells, due to the high cost of creating hydrogen from standard grid electricity. Current government tax reductions and subsidies can be used to minimize the cost of installing an on-site renewable energy system.

\section{Address Codes and Standards}

It was often observed that the Authority Having Jurisdiction (AHJ) was not well-informed on the codes and standards. In many cases, AHJ asked whether the fuel cell installation followed the codes and standards, but was unable to advise what codes, regulations and standards have to be followed. Another issue was that different locations followed different code and standards, leading to the circumstances where certain fuel cell installers had to go through stricter codes and standards than others.

In some cases the installer assisted in formulating codes and standards. From the study, it is evident that there should be consistent codes, regulations, and standards. Consequently, AHJ should be informed of the codes and standards for fuel cell application or at least should have access to it. For on-site hydrogen storage installations, consult local stakeholders early in the planning stage to alleviate from complications which may arise in the installation phase. A 
reduction in customer apprehension would also help policy makers move forward with other recommendations.

\section{Safety and Environment}

Safety is a critical issue not only for the design and operation of hydrogen-powered systems but also for the public perception and market penetration of such new technology. Safety practices of hydrogen applications are generally based on experiences from other traditional fuels whose properties are drastically different from those of hydrogen. Among others, key concerns are its low ignition energy, low luminosity, high flame speed, and wide flammability range. System and component design should accommodate the above special characteristics of hydrogen. Thus, cutting edge research in hydrogen safety and environmental impacts should be one of the focus areas. Additionally, lack of environmental considerations in energy generation and utilization has lead to a number of national-level programs that had tremendous environmental detriment, even though conceived to address environmental concerns. Thus, research must scientifically address the environmental footprint of hydrogen fuel generation, storage and utilization.

\subsection{Summary and Conclusions}

The role and use of fuel cells in near-term stationary and portable applications (such as residential/base combined heat and power, backup and auxiliary power, grid independent power, specialty vehicles, and portable devices) could be significant, especially if opportunities for integrated systems are considered. During the past 20 years, a number of approaches have been used to encourage the application of alternative fuels and fuel technologies; however, many of these have failed due to lack of a real program management support, shifts in government policies, and/or failure to considered technical experience from previous efforts. Lessons learned with respect to the lack of success and widespread acceptance of fuel cell technologies, as well as other technologies developed for stationary and portable fuel cell systems, may be used to provide recommendations for market research and transformation strategies. 
Successful demonstration of fuel cell technologies is crucial to the long-term sustainability of fuel cell technologies; thus, market studies are intertwined within technical research. Therefore, efforts should explicitly address interactions by rigorously considering the science behind, among others, technology status and growth, applications for early market development, consumer behavior and attitudes, impact of infrastructure availability, e.g., cost and environmental parameters, and transitional dynamics of fuel cell technologies, infrastructure, and applications. Lessons learned from prior fuel cell programs, including the most significant obstacles, how these obstacles have been approached, outcomes of the programs, can be used to encourage the use of fuel cells are still required.

This study analyzed different strategies utilized in power generation systems in order to identify the different challenges and opportunities for producing and using hydrogen as an energy carrier. By acquiring the fuel cell customers/end-users opinion on the current status of the stationary and portable fuel cell markets (through interviews, conferences, meetings, and workshops), knowledge has been gained that addresses what steps should be taken in regard to making recommendations for bringing more customers into the fuel cell market. The understanding of competitive and technological issues related to feasible alternatives allows for effective short and long term strategies for addressing the nation's energy challenges. Highlighted conclusions include:

- The role and use of hydrogen fuel cells in stationary applications can be significant in portable applications, niche markets, distributed generation or co-generation.

- Market penetration is the ultimate goal of the energy related industries, but early markets must be strategically aligned with balancing near term and long term objectives.

- Focus on demonstrating that cost, durability, and reliability can be met for early markets (with incentives, if necessary).

- Consider opportunities and trade-offs for stationary applications in conjunction with the other application sectors, e.g., providing fuel for transportation applications.

- Take a systems perspective - components should address multiple systems.

The ideal candidates for stationary fuel cell deployment include applications that require constant, consistent, reliable, quiet power, can effectively use waste heat for heating and cooling, 
and have potential uses for by-product hydrogen. While proven and accepted mass market fuel cell technology development and cost reduction is taking longer than expected, some applications have broken the mold and are cost competitive with incumbent technology.

Market barriers include technical considerations, cost competitiveness, fuel flexibility, and public acceptance. These can be addressed through a strategy that:

1. Continues Demonstration Projects

2. Focuses on Application Specific Competition

3. Facilitates Investment through Tax Credits, Subsidies, and Financial Partnerships

4. Prioritizes R\&D Efforts

5. Shows Value Proposition through Niche Markets

6. Encourages Integrated Systems

7. Addressed Codes/Standards, Safety and Environment

Future work should continue to address these technical, economic, and social barriers to widespread market growth. 


\section{APPENDIX A: CONFERENCES/MEETINGS/WORKSHOPS/SITE VISITS}

DOE Fuel Cell Pre-Solicitation Workshop January 23-24, 2008

Member of the project team attended the DOE Workshop to join the fuel cell research community and other stakeholders in a discussion of the most relevant fuel cell technology research, development, and demonstration topics related to automotive, stationary, portable power, and early market applications. The meeting provided valuable information on early market strategies and will be used as a foundation for the Missouri S\&T sponsored workshop.

National Hydrogen Association 2008 Annual Conference March 30 - April 4, 2008.

A poster and two papers were presented at the NHA 2008 Annual Conference. The theme was "Ramping Up Commercialization." As a result, a major focus of the Conference and Expo will be the challenges and opportunities in early markets, as well as ways to advance the commercial use of hydrogen products currently available in the marketplace. In addition to presentation of preliminary work, this was an opportunity to network with industry leaders and learn about the latest technology and research.

Specifically, the following presentations were made:

- Grasman, S.E., Liu, Z., and Martin, K.B., "Transitional Hydrogen Supply Chain Infrastructure Modeling", National Hydrogen Association Annual Conference, Sacramento, April 2008.

- Grasman, S.E., Sheffield, J.W., and Martin, K.B., "Strategies for Stationary Power Generation", National Hydrogen Association Annual Conference, Sacramento, April 2008.

- Sheffield, J.W., Krishnamurthy, K., Lee, S., Grasman, S.E., and Martin, K.B., "Show Me the Road to Hydrogen", National Hydrogen Association Annual Conference, Sacramento, March 2008. 
CeSSA Conference on Prospects for a European Hydrogen Economy, April 14-15, 2008.

The main objective of this meeting is to explore the role to be possibly played by hydrogen in the context of the security of energy supply in the EU. At the moment, hydrogen is a promising alternative. However, in order for hydrogen to become a working part of the energy system, huge amounts have to be invested in research, development and new infrastructure. The conference aims at clarifying the magnitude of the challenge, identifying the most promising tracks to be followed, and setting the frame to discuss the expected gains, given the expected costs.

DOE Hydrogen Program Merit Review, June 9-13, 2008

The project was reviewed for their merit during the Annual Merit Review and Peer Evaluation Meeting. A presentation was provided and reviewed.

IEEE International Engineering Management Conference, Estoril, Portugal, June 28 - 30, 2008,

A poster was presented related to the theme of "Managing Engineering, Technology and Innovation for Growth." As a result, a major focus related to challenges and opportunities in early markets, as well as ways to advance the commercial use of hydrogen products currently available in the marketplace. In addition to presentation of preliminary work, this was an opportunity to network with industry leaders and learn about the latest technology and research.

Specifically, the following presentation was made:

- Grasman, S.E., Faulin, J., and Lera, F., "Public-Private Partnerships for Technology Growth in the Public Sector", IEEE International Engineering Management Conference, Estoril, Portugal June 28 - 30, 2008.

Global Conference on Global Warming, Istanbul, Turkey, July 6-10, 2008.

The Global Conference on Global Warming 2008 (GCGW-08) covered a broad range of topics on energy and environment policies, energy resources, energy conversion technologies, energy management and conservation, energy security, renewables, green technologies, emission reduction and abatement, carbon tax, sustainable development, pollution control and measures, 
and policy development. The conference provided an exciting technical program with the role of the fuel cells as one of the key topic areas. Market penetration of the PEM fuel cells can also be viewed from a global warming perspective which we may solicit for our planned meetings and conferences.

The following paper was presented:

- Dogan, F., Grasman, S.E., and Sheffield, J.W., "Fuel Cell and Hydrogen Transportation Test Bed Development at the Missouri University of Science and Technology", Global Conference on Global Warming, Istanbul, July 2008.

Fuel Cell Seminar \& Exposition, Phoenix, Arizona October 27-30, 2008

With over 2000 participants and 175 exhibiting companies, the Fuel Cell Seminar \& Exposition was one of the largest and most influential conferences of its kind. Project investigators attended to network with industry leaders, solicit study participants, and potential site visits.

US Fuel Cell Council Webinar, November 20, 2008

The following webinar was presented to the US Fuel Cell Council:

- Grasman, S.E., "Hydrogen and Fuel Cell Analysis: Lessons Learned from Stationary Power Generation", US Fuel Cell Council, November 2008.

Annual Military Energy Alternatives, Washington DC, January 12-14, 2009

The $4^{\text {th }}$ Annual Military Energy Alternatives conference addressed the challenges faced by the Department of Defense and the use of alternative energy applications systems. It sought to identify alternative energy options available to the military specifically examining the cost and efficiency of each option. Specific topics included the development and use of portable power and the use of hydrogen and hydrogen fuel cells. 
Hydrogen Village, Toronto Area, Ontario, Canada, January 18-19, 2009

The goal of Hydrogen Village is to lead the way to a green and sustainable energy future by raising awareness and breaking down barriers to markets for hydrogen, fuel cell and other relevant technologies within the Greater Toronto Area. The area is home to a growing cluster of unique, sustainable hydrogen and fuel cell projects. These projects illustrate that the hydrogen economy is not a dream for the distant future. Hydrogen and fuel cell technology has realistic applications for today.

Fuel Cell /Stationary Power Research Seminar, January 28, 2009

William R. Taylor has a B.S. in Electrical Engineering from the University of Missouri - Rolla, and has been involved with fuel cell technology since 1995. From 1995-2005, Bill worked on a team that managed the DOD Fuel Cell Demonstration Program which resulted in the installation of 30 Phosphoric Acid (PAFCs) and numerous PEM fuel cells at DOD installations across the continental U.S. and Alaska. Since 2005, Bill has worked for LOGANEnergy, a small fuel cell services company, implementing numerous fuel cell projects. Bill provided a brief introduction to fuel cell technology, followed by an overview of several fuel cell hardware packages used in projects over the past 15 years. Project experiences from dozens of real world applications were shared with consideration of implications for future possibilities.

US Fuel Cell Council Board/Members Meeting, March 10-11, 2009

The US Fuel Cell Council is an industry association dedicated to fostering the commercialization of fuel cells. Our members include the world's leading fuel cell developers, manufacturers, suppliers and customers.

The following presentation was made to the board/members meeting.

- Grasman, S.E., "Hydrogen and Fuel Cell Analysis: Lessons Learned from Stationary Power Generation”, Fuel Cell Council Board Meeting, March 10, 2009. 
Missouri Energy Summit, Columbia, Missouri, April 22-23, 2009

The Missouri Energy Summit brought together faculty and researchers, businesses, entrepreneurs and venture capitalists from across the state and beyond, along with federal and state agencies, to explore and showcase Missouri's cutting-edge research and development efforts in energy, alternative fuel sources, power, storage, infrastructure and enabling technologies. The summit highlighted successes and provided guidance for the future. The summit was a content-rich two days with national, state and local speakers, including T. Boone Pickens, a visionary in our nation's future energy strategy.

The following poster was presented.

- Grasman, S.E., "Fuel Cell Policy Recommendations”, Missouri Energy Summit, April, 2009.

MS\&T Sponsored Workshop, Columbia, South Carolina, April 2, 2009

A Stationary \& Portable Fuel Cell Market Transformation and Applications workshop was held at the NHA Conference and Hydrogen Expo to follow-up on the initial results from the study and to gather opinions on near-term market hydrogen applications and policy recommendations. About 40 active members of the fuel cell community participated in the workshop and additional data and lessons learned and recommendations were collected during the workshop. The workshop consisted of four presentations describing the potential markets in the fuel cell industry and two break-out sessions. The break out session provided information on the impediments to the fuel cell market and the challenges faced in establishing codes and standards.

Industrial Engineering Research Conference - Innovations Revealed, Miami, May/June2009.

Preliminary results from the study, initially collected through the National Fuel Cell Council and to the attendees of the 2008 Fuel Cell Seminar were presented. The presentation provided a synopsis/critical analysis of lessons learned from previous stationary power programs, which should be taken into consideration in order to make recommendations related to RD\&D 
strategies that incorporate lessons learned and best practices from relevant stationary power efforts.

The following paper was presented:

- Cottrell, C., and Grasman, S.E., "A Preliminary Study on Stationary and Portable Fuel Cell Applications", Industrial Engineering Research Conference, Miami, May 2009.

DOE Hydrogen Program Merit Review, May 18-19, 2009

The project was reviewed for their merit during the Annual Merit Review and Peer Evaluation Meeting. A presentation was provided and reviewed.

HYSYDAYS 2009 - 3rd World Congress of Young Scientists on Hydrogen Energy Systems, Torino, Italy, October 7-9, 2009

The Congress focuses on young scientists and all of them are invited to submit their contribution. Authors were invited to submit a full paper to be published in a Special Issue of the International Journal of Hydrogen Energy with a peer reviewed selection of the papers presented by young scientists at the 3rd edition of the Congress. To be publishable in the Special Issue of the International Journal of Hydrogen Energy the papers have to be presented by one of the authors at the Congress. Five special Awards were assigned to the best works evaluated by the scientific committee. The following paper received a best paper award:

- Cottrell, C., Grasman, S.E., Thomas, M., Martin, K.B., and Sheffield, J.W., "Best Practices for Stationary and Portable Fuel Cell Markets", World Congress of Young Scientists on Hydrogen Energy Systems, Turin, October 2009.

INFORMS 2009 - Annual Meeting of the Institute for Operations Research and the Management Sciences, San Diego, October 11-14, 2009

The Institute for Operations Research and the Management Sciences (INFORMS) is the largest professional society in the world for professionals in the field of operations research. The following presentation was invited as part of the telecommunications section: 
- Grasman, S.E., “Fuel Cells in Telecommunications Applications” INFORMS Annual Meeting, October 2009.

This presentation addresses the potentially significant role and use of fuel cells in telecommunications. Technology status and growth, early market development, consumer behavior and attitudes, impact of infrastructure availability, and transitional dynamics of fuel cell technologies, infrastructure, and applications are analyzed, including the most significant obstacles, how these obstacles have been approached, and how this information can be used to encourage the use of fuel cells.

Exhibit at Fuel Cell Seminar and Exposition, Palm Springs, California, November 16-20, 2009

The exhibit was held at the Fuel Cell Seminar and Exposition. Additional project data was solicited via discussions with exhibitors and patrons. In addition, the following poster was presented.

- Rodgers, S.F., Koylu, U.O., and Grasman, SE., , "Validation of Software for Simulating PEM Fuel Cells,” 2009 Fuel Cell Seminar \& Exposition, Palm Springs, CA, November 16-19, 2009.

\section{Edited Book}

The project lead is editing a book on Hydrogen Energy and Vehicle Systems for CRC/Taylor and Francis. The book is targeted for publication in Spring 2011. 


\section{APPENDIX B: BIBLIOGRAPHY}

[1] Department of Energy, 2009, “Department of Energy - Hydrogen,” Department of Energy website, http://www.energy.gov/energysources/hydrogen.htm/.

[2] Baker, A., and Adamson, K., 2005, "Fuel Cell Today Market Survey: Large Stationary Applications”, Fuel Cell Today, 2 November 2005

[3] Brdar, D., Bentley, C., Farooque, M., Oei, P, and Rauseo, T., 2006, “Stationary Fuel Cell Power Plants Status”, Fuel Cells Seminar and Exposition.

[4] Nishikawa, S., 2006, "Current Status of the Large-Scale Stationary Fuel Cell Demonstration Project in Japan”, Fuel Cell Seminar and Exposition.

[5] Garibaldi, P., 2005, "Italian H2 Parks and Projects: Towards as Inter-Regional 'Lighthouse' Action Plan, IPHE SC Meeting, Paris.

[6] Tulloch, M., 2006, “Hebridean Hydrogen Park: Business Plan 2006-2008”, Energy Innovation Zone.

[7] Mahadevan, K. Judd, K., Stone, H., Zewatsky, J., Thomas, A. Mahy, H., Paul, D., 2007, "Identification and Characterization of Near-Term Direct Hydrogen Proton Exchange Membrane Fuel Cell Markets”, Market Research Study by Battelle for DOE Contract No. DE-FC36-03GO13110.

[8] Kurtz, J., Ramsden, T., Wipke, K., Sprik, S. 2009, "Data Analysis of Early Fuel Cell Market Demonstrations” presentation, Fuel Cell Seminar and Exposition.

[9] Engineer Research and Development Center (ERDC) - Construction Engineering Research Laboratory (CERL) Fuel Cell website, PAFC Demonstration http://dodfuelcell.cecer.army.mil/pafc/index.php.

[10] Engineer Research and Development Center (ERDC) - Construction Engineering Research Laboratory (CERL) Fuel Cell website, Climate Change Rebate Project Overview. http://dodfuelcell.cecer.army.mil/climate/index.php.

[11] Engineer Research and Development Center (ERDC) - Construction Engineering Research Laboratory (CERL) Fuel Cell website, Residential Demonstration Overview. http://dodfuelcell.cecer.army.mil/res/index.php.

[12] White, M.K., Holcomb, F.H., Josefik, N.M., Lux, S.M., Binder, M.J., 2004, DOD Residential Proton Exchange Membrane (PEM) Fuel Cell Demonstration Program Volume I - Summary of the Fiscal Year 2001 Program. 
[13] White, M.K., Lux, S.M., Knight, J.L., Binder, M.J., Holcomb, F.H., Josefik, N.M., 2005. DOD Residential Proton Exchange Membrane (PEM) Fuel Cell Demonstration Program Volume II - Summary of the Fiscal Year 2001-2003 Projects.

[14] Milliken, J., Satyapal, S., Devlin, P., Christensen, J, 2009, “Update on Progress and Opportunities at the Department of Energy and the Department of Defense” presentation, U.S. Fuel Cell Council Members Meeting, March 10, 2009.

[15] FY 2009 Financial Awards, U.S. Department of Energy's Office of Energy Efficiency and Renewable Energy, Hydrogen and Fuel Cell Financial Opportunities website, http://www1.eere.energy.gov/hydrogenandfuelcells/2009_financial_awards.html.

[16] Japan's Fuel Cell Industry, JETCO Economic Report, April/May 2006. http://www.jetro.go.jp/en/market/report/pdf/2006_23_ahs.pdf.

[17] Japan Hydrogen \& Fuel Cell Demonstration Project website, http://www.jhfc.jp/e/.

[18] ATIP Document ID: 080321S Monitoring Program for Residential Fuel Cell System in Korea, available at:

http://www.atip.org/node/pubs/scoops/Scoop-MonitoringProgramForResidentialFuelCellSystemKorea.pdf

[19] California Stationary Fuel Cell Collaborative Projects website, http://www.casfcc.org/2/AboutUs/Projects.aspx.

[20] Moreland, G., 2008, "Fuel Cells for Critical Communications Backup Power”, APCO Annual Conference and Expo.

[21] New York Power Authority Fuel Cell Projects website, http://www.nypa.gov/wwwnypagov/wwwroot/services/fuel\%20cell\%20projects.htm

[22] Spitznagel, K.A., 2002, “First National Bank of Omaha Applying Four 200 Kilowatt Fuel Cells in a Mission Critical Installation Final Report”, Climate Change Fuel Cell Program.

[23] South Carolina Hydrogen and Fuel Cell Alliance website, http://www.schydrogen.org/.

[24] Kaundinya, D.P., Balachandra, P., Ravindranatha, N.H., 2009, “Grid-Connected Versus Stand-alone Energy Systems for Decentralized Power-A Review of Literature”, Renewable and Sustainable Energy Reviews, Volume 13, Issue 8, Pages 2041-205.

[25] Ricci, M. Bellaby, P. Flynn, R., 2008, "What do we know about public perceptions and acceptance of hydrogen? A critical review and new case study evidence”, International Journal of Hydrogen Energy, Volume 33, Pages 5868-5880. 
[26] Varkaraki, E., Lymberopoulos, N., Zoulias, E., Guichardot, D., Poli, G., 2007, "Hydrogen-based Uninterruptible Power Supply", International Journal of Hydrogen Energy, Volume 32, Issues 10-11, July-August 2007, Pages 1589-1596.

[27] Bompard, E., Napolia, R., Wan, B. Orsello, G., 2008, "Economics Evaluation of a 5kW SOFC Power System for Residential Use”, International Journal of Hydrogen Energy, Volume 33, April 2008, Pages 3243-3247.

[28] Young, D.C., Mill, G.A., Wall, R., 2007, "Feasibility of Renewable Energy Storage using Hydrogen in Remote Communities in Bhutan”, International Journal of Hydrogen Energy, Volume 32, Issue 8, June 2007, Pages 997-1009.

[29] Gaines, L., Elogowainy, A., Wang, M., 2008, “Full Fuel Cycle Comparison of Forklift Propulsion Systems”, ANL/ESD/08-3 - Argonne National Laboratory.

[30] Agnolucci, P., 2007, “Economics and Market Prospects of portable Fuel Cells”, International Journal of Hydrogen Energy, Volume 32, May 2007, 4319-4328.

[31] Kamarudin, S.K., Achmad, F., Daud, W.R.W., 2009, "Overview on the Application of Direct Methanol Fuel Cells for Portable Electronic Devices”, International Journal of Hydrogen Energy, Volume 34, 6902-6916.

[32] Dwyer, F.R., Tanner, Jr., J.F., 2009, "Business Marketing: Connecting Strategy, Relationships, and Learning”, McGraw-Hill.

\section{Additional References not Cited (in Alphabetical Order)}

Bischoff, M., 2006, “Large Stationary Fuel Cell Systems: Status and Dynamic Requirements”, Journal of Power Sources Volume 154, 461-466.

Bompard, E., Napoli, R., Orsello, G., Roiu, D., Tenconi, A., Wan, B., 2008, “Technical Considerations of SOFCs for Mixed DG/Backup Power Applications”, International Journal of Hydrogen Energy, Volume 33, 6743-6748.

Cruden, A., Houghton, T., Gair, S., Duerr, M., Agnew, G.D., Stewart, E.M., Lutz, A., 2008, “Fuel Cells as Distributed Generation”, Volume 222, 707-720.

Gencoglu, M.T., Ural, Z., 2009, "Design of a PEM Fuel Cell System for Residential Application”, International Journal of Hydrogen Energy, Volume 34, 5242, 5248.

Ramirez-Salgado, J., Dominquez-Aquilar, M.A., 2009, “Market Survey of Fuel Cells in Mexico: Niche for Low Power Portable Systems”, Journal of Power Systems, Volume 186, 455-463. 
Segura, F., Duran, E., Andujar, J.M., 2009, "Design, Building and Testing of a Stand Alone Fuel Cell Hybrid System”, Journal of Power Sources, Volume 193, 276-284.

Sisworahardjo, N.S., Alam, M.S., Aydinli, G., 2008, "Reliability and Availability Analysis of Low Power Portable Direct Methanol Fuel Cells”, Journal of Power Sources, Volume 177, 412418.

Varkaraki, E., Lymberopoulos, N., Zachariou, A., 2003, "Hydrogen Based Emergency Back-up System for Telecommunications Applications”, Journal of Power Systems, Volume 118, 14-22.

Zhan, Y., Guo, Y., Zhu, J., Want, H., 2008, “Intelligent Uninterruptible Power Supply System with Back-Up Fuel Cell/Battery Hybrid Power Source”, Journal of Power Sources, Volume 179, 745-753.

\section{Publications/Presentations Resulting from Project (in Chronological Order):}

Grasman, S.E., Liu, Z., and Martin, K.B., "Transitional Hydrogen Supply Chain Infrastructure Modeling", National Hydrogen Association Annual Conference, Sacramento, April 2008.

Grasman, S.E., Sheffield, J.W., and Martin, K.B., "Strategies for Stationary Power Generation", National Hydrogen Association Annual Conference, Sacramento, April 2008.

Sheffield, J.W., Krishnamurthy, K., Lee, S., Grasman, S.E., and Martin, K.B., "Show Me the Road to Hydrogen", National Hydrogen Association Annual Conference, Sacramento, March 2008.

Grasman, S.E., Faulin, J., and Lera, F., "Public-Private Partnerships for Technology Growth in the Public Sector", IEEE International Engineering Management Conference, Estoril, Portugal June 28 - 30, 2008.

Dogan, F., Grasman, S.E., and Sheffield, J.W., "Fuel Cell and Hydrogen Transportation Test Bed Development at the Missouri University of Science and Technology", Global Conference on Global Warming, Istanbul, July 2008.

Grasman, S.E., "Hydrogen and Fuel Cell Analysis: Lessons Learned from Stationary Power Generation", US Fuel Cell Council, November 2008.

Grasman, S.E., "Hydrogen and Fuel Cell Analysis: Lessons Learned from Stationary Power Generation", Fuel Cell Council Board Meeting, March 10, 2009.

Grasman, S.E., "Topic 1: Early Fuel Cell Market Applications with High Volume Potential", Response to Request for Information DE-PS36-09GO3900. 
Grasman, S.E., "Fuel Cell Policy Recommendations", Missouri Energy Summit, April, 2009.

Cottrell, C., and Grasman, S.E., "A Preliminary Study on Stationary and Portable Fuel Cell Applications", Industrial Engineering Research Conference, Miami, May 2009.

Cottrell, C., Grasman, S.E., Thomas, M., Martin, K.B., and Sheffield, J.W., "Best Practices for Stationary and Portable Fuel Cell Markets", World Congress of Young Scientists on Hydrogen Energy Systems, Turin, October 2009.

Grasman, S.E., "Fuel Cells in Telecommunications Applications", INFORMS Annual Meeting, October 2009.

Rodgers, S.F., Koylu, U.O., and Grasman, SE., , "Validation of Software for Simulating PEM Fuel Cells", 2009 Fuel Cell Seminar \& Exposition, Palm Springs, CA, November 16-19, 2009.

Rodgers, S.F., Vudumu, S.K., Koylu, U.O., Murray, S.L., and Grasman, S.E., "Hydrogen Safety in Power Generation Applications", Journal of the American Society of Safety Engineers (in press).

Cottrell, C.A., Grasman, S.E., Thomas, M., Martin, K.B., and Sheffield, J.W., "Best Practices for Stationary and Portable Fuel Cell Markets", International Journal of Hydrogen Energy (conditionally accepted). 


\section{APPENDIX C: PROGRAM WEBSITES}

\section{United States}

California Stationary Fuel Cell Collaborative

http://www.casfcc.org/

DODFuelCell ERDC/CERL Projects

http://dodfuelcell.cecer.army.mil//

DoE EERE Hydrogen, Fuel Cells \& Infrastructure Technologies Program

http://www1.eere.energy.gov/hydrogenandfuelcells/

Fuel Cells 2000

http://www.fuelcells.org/

National Fuel Cell Research Center

http://www.nfcrc.uci.edu/

US Fuel Cell Council

http://www.usfcc.com/

\section{International}

\section{Canada}

Canadian Transportation Fuel Cell Alliance (CTFCA), http://www.nrcan.gc.ca/es/etb/ctfca/index_e.html

The Canadian Transportation Fuel Cell Alliance (CTFCA), managed by Natural Resources Canada (NRCan), is an important element of the federal government's climate change strategy.

The \$33 million initiative was established in 2001 and has received funding through to March 2008. The CTFCA focuses its efforts on showcasing hydrogen fuelled vehicles and hydrogen fuelling station demonstration projects. It also evaluates options for the production and delivery of hydrogen to light-, medium- and heavy-duty vehicles, monitors the resulting greenhouse gas emission reductions and develops training, certification and safety standards in support of hydrogen and fuel cell technologies. 


\section{Hydrogen \& Fuel Cells Canada}

http://www.fuelcellscanada.ca/

Hydrogen \& Fuel Cells Canada is the national industry association dedicated to accelerating Canada's world-leading hydrogen and fuel cell industry.

National Research Council (Canada)

http://www.nrc-cnrc.gc.ca/randd/areas/fuelcells_e.html

http://ifci-iipc.nrc-cnrc.gc.ca/main_e.html

The National Research Council (NRC) plays a major role in the development of fuel cell technology. The NRC Fuel Cell Program brings together valuable expertise from six different NRC research institutes. The NRC Institute for Fuel Cell Innovation (NRC-IFCI) in Vancouver is home to the NRC Fuel Cell Program. In collaboration with industry, universities and other government agencies, the program provides research and innovation support in areas critical to the growth of the sector, such as fuels research, system integration and manufacturing and component development.

The true economic value of fuel cells lies in an entire system of supporting products and technologies. Fuel cell research at NRC focuses on a number of areas integral to the growth of the sector. NRC has also funded major capital projects to expand the number of hydrogen-safe labs and to provide testing facilities specialized for different fuel cell sizes and different fuel cell types. NRC provides 3500 square feet of hydrogen-safe laboratory space. The Institute offers testing facilities specialized for different fuel-cell sizes and different fuel-cell types, demonstration facilities to showcase new technology, incubation space for start-ups, and access to specialized information resources.

NRC-IFCI is Canada's premier applied research organization dedicated to supporting Canada's fuel cell and hydrogen industry. NRC-IFCI works independently and in partnership with companies, research organizations, universities, and government agencies on projects focused on the research, development, demonstration and testing of hydrogen and fuel cell systems. This mandate delivers on the Government of Canada's climate change and innovation priorities and responds to Canada's Fuel Cell Commercialization Roadmap, which identified critical areas of 
research necessary for Canadian industry to overcome cost, performance and reliability challenges of hydrogen and fuel cell technologies. Our culture and business practices are collaborative. We work closely with industry, academia and other government agencies, both domestic and international, on projects focused on the research, development, demonstration, and testing of hydrogen and fuel cell systems.

\section{Japan}

Fuel Cell Development Information Center http://www.fcdic.com/eng/

The Fuel Cell Development Information Center was established in July 1986 to exchange information among its members on fuel cell research, development and deployment aiming at the introduction and penetration of fuel cells into the market. Currently, FCDIC consists of more than 200 organizations, including major Japanese private companies and national organizations working on fuel cell development, 65 academic individuals, and 10 foreign members. Fuel cells are going to play an extremely important role as an energy source for the next generation. In view of its importance, we will continue to strive for the early commercialization and diffusion of the fuel cell systems.

\section{Worldwide}

European Hydrogen and Fuel Cell Technology Platform (HFP) https://www.hfpeurope.org/

The European Hydrogen and Fuel Cell Technology Platform (HFP) facilitates and accelerates the development and deployment of cost-competitive, world class European hydrogen and fuel cell based energy systems and component technologies for applications in transport, stationary and portable power. The European Hydrogen \& Fuel Cell Technology Platform ensures a balanced and active participation of all major stakeholders in Europe. Organizations active in HFP include industry from SMEs to multinational companies, the scientific community, public authorities, users as well as civil society. All stakeholders active in Hydrogen \& Fuel Cells are invited to contribute actively to the work of the HFP. For this, please contact the chair of the respective HFP body. 
The High Level Group on Hydrogen and Fuel Cells was formally launched in Brussels on 10th October 2002 by the Vice President of the European Commission and Research Commissioner. It brings together top-level stakeholders from across Europe representing a broad cross section of interests, with the aim of formulating an integrated EU vision on the possible role that hydrogen and fuel cells could play in achieving sustainable energy. It will also address what would be required to achieve global leadership in this field in the next 20 to 30 years.

International Partnership for the Hydrogen Economy (IPHE)

http://www.iphe.net/

The International Partnership for the Hydrogen Economy was established in 2003 as an international institution to accelerate the transition to a hydrogen economy. The IPHE Partners members include:

- Australia

- Brazil

- Canada

- China

- European Commission

- France Germany

- Iceland

- India
- Italy

- Japan

- Republic of Korea New Zealand

- Norway

- Russian Federation

- United Kingdom

- United States

By creating the IPHE, the Partners have committed to accelerate the development of hydrogen and fuel cell technologies to improve their energy security, environmental security and economic security by providing a mechanism for partners to organize, coordinate and implement effective, efficient, and focused international research, development, demonstration and commercial utilization activities related to hydrogen and fuel cell technologies. The IPHE provides a forum for advancing policies, and common technical codes and standards that can accelerate the costeffective transition to a hydrogen economy; and it educates and informs stakeholders and the general public on the benefits of, and challenges to, establishing the hydrogen economy. 


\section{APPENDIX D: DATABASES}

Developers of Fuel Cells (Worldwide)

http://www.fuelcells.org/info/fcdev.html

The Ninth Edition of the Fuel Cell Directory contains 1035 companies, complete with contacts and descriptions. To check for companies in your area, see our interactive map of fuel cell developers. The US Fuel Cell Council has released a comprehensive list of fuel cell products available for purchase from manufacturers headquartered in the United States, Canada and Europe. The database contains businesses, institutes and organizations that are involved in development of fuel cell stacks with links to web sites and notes related to technology type.

\section{Fuel Cells Today}

http://www.fuelcelltoday.com/

Fuel Cell Today's surveys on fuel cell and hydrogen markets have become the industry standard. Since 2001 they have published free-to-download surveys, providing an overview of developments by sector, tracking and interpreting market trends. Their surveys cover the full range of fuel cell applications, including: transportation, military, portable electronics, small and large stationary power generation, niche segments, infrastructure and fuelling. The majority of our surveys cover their topic from a global perspective, with the exception being those which highlight activities in a particular country or region.

\section{Hydrogen Demonstration Project Atlas}

http://www.iphe.net/newatlas/atlas.htm

The atlas is an interactive international atlas of hydrogen and fuel cell demonstration projects developed by the IPHE, which currently contains information on approximately 300 projects worldwide. 


\section{Stationary Fuel Cell Installation Database}

http://www.fuelcells.org/info/databasefront.html

This database catalogues stationary fuel cell installations worldwide - past, present and some planned. There have been more than 2,000 fuel cells around the world since the early 1980s. Some locations in the database have more than one fuel cell unit installed. To ensure the database works properly, please use the buttons on the database screen. There is a basic as well as an advanced search feature that allows you to narrow down your search by multiple fields.

To find out more about a specific fuel cell manufacturer, visit our Fuel Cell Developers page.

\section{State Fuel Cell and Hydrogen Database}

http://www.fuelcells.org/info/statedatabase.html

This database catalogues initiatives, policy and partnerships in the fuel cell and hydrogen arena. We also include all stationary fuel cell installations, hydrogen fueling stations and vehicle demonstrations in the United States. This database sparks activity to help bring fuel cells to commercialization and the hydrogen economy to realization. We have only included installations, vehicle demonstrations and hydrogen fueling stations that we know are either open right now or that have already ended. For planned hydrogen fueling stations, please check out our Hydrogen Fueling Station Chart and for planned stationary fuel cell installations; please visit our Worldwide Stationary Fuel Cell Installation Database.

For a comprehensive state-by-state analysis of state programs and incentives that specifically include hydrogen, fuel cells and zero emission vehicles, check out our State Activities That Promote Fuel Cells and Hydrogen Infrastructure Development report. For information on federal programs and activities, please visit DOE's Hydrogen Program website. For more information on hydrogen and other alternative fuels, please visit the Alternative Fuels Data Center. Alternative fuels described here are those defined by the Energy Policy Act of 1992, including biodiesel, electricity, ethanol, hydrogen, natural gas, and propane. This site has more than 3,000 documents in its database, an interactive fuel station mapping system, current listings of available alternative fuel vehicles, and lots of alternative fuels information and related links. For additional information on state, local, utility, and Federal incentives for energy efficiency and renewable energy, check out the North Carolina Solar Center's Database of State Incentives for Renewables \& Efficiency (DSIRE). 